\title{
Review Article \\ Recent Advances in Imaging of Dopaminergic Neurons for Evaluation of Neuropsychiatric Disorders
}

\author{
Lie-Hang Shen, Mei-Hsiu Liao, and Yu-Chin Tseng \\ Institute of Nuclear Energy Research, Jiaan Village, Lungtan Township, Taoyuan 32546, Taiwan \\ Correspondence should be addressed to Yu-Chin Tseng, yctseng@iner.gov.tw
}

Received 15 December 2011; Accepted 27 January 2012

Academic Editor: David J. Yang

Copyright () 2012 Lie-Hang Shen et al. This is an open access article distributed under the Creative Commons Attribution License, which permits unrestricted use, distribution, and reproduction in any medium, provided the original work is properly cited.

Dopamine is the most intensely studied monoaminergic neurotransmitter. Dopaminergic neurotransmission plays an important role in regulating several aspects of basic brain function, including motor, behavior, motivation, and working memory. To date, there are numerous positron emission tomography (PET) and single photon emission computed tomography (SPECT) radiotracers available for targeting different steps in the process of dopaminergic neurotransmission, which permits us to quantify dopaminergic activity in the living human brain. Degeneration of the nigrostriatal dopamine system causes Parkinson's disease (PD) and related Parkinsonism. Dopamine is the neurotransmitter that has been classically associated with the reinforcing effects of drug abuse. Abnormalities within the dopamine system in the brain are involved in the pathophysiology of attention deficit hyperactivity disorder (ADHD). Dopamine receptors play an important role in schizophrenia and the effect of neuroleptics is through blockage of dopamine $\mathrm{D}_{2}$ receptors. This review will concentrate on the radiotracers that have been developed for imaging dopaminergic neurons, describe the clinical aspects in the assessment of neuropsychiatric disorders, and suggest future directions in the diagnosis and management of such disorders.

\section{Introduction}

Neuropsychiatric disorders cause severe human suffering and are becoming a major socioeconomic burden to modern society. The rapid development of noninvasive tools for imaging human brains will improve our understanding of complex brain functions and provide more insight into the pathophysiology of neuropsychiatric disorders. Neuroimaging techniques currently utilized in neuropsychiatric disorders include a variety of modalities, such as ultrasound, Xrays, computed tomography (CT), functional magnetic resonance imaging (fMRI), and nuclear medicine imaging [1].

The interactions between transporters/receptors and neurotransmitters play a key role in the diagnosis and treatment of neuropsychiatric disorders. In contrast with conventional diagnostic imaging procedures, which simply provide anatomical or structural pictures of organs and tissues, nuclear medicine imaging is the only tool to visualize the distribution, density, and activity of neurotransmitters, receptors, or transporters in the brain. Nuclear medicine imaging involves the administration of radioactively labeled tracers, which decay over time by emitting gamma rays that can be detected by a positron emission tomography (PET) or single photon emission computed tomography (SPECT) scanner [2, 3]. PET uses coincidence detection in lieu of absorptive collimation to determine the positronelectron annihilation, which produces two $511 \mathrm{keV}$ photons in opposite direction. This partially explains the greater spatial resolution and sensitivity of PET. Radioisotopes used in PET imaging typically have short physical half-life and consequently many of them have to be produced with an on-site cyclotron. Radioisotopes used for labeling PET radiopharmaceuticals include ${ }^{11} \mathrm{C},{ }^{13} \mathrm{~N},{ }^{15} \mathrm{O},{ }^{18} \mathrm{~F},{ }^{64} \mathrm{Cu},{ }^{62} \mathrm{Cu}$, ${ }^{124} \mathrm{I},{ }^{76} \mathrm{Br},{ }^{82} \mathrm{Rb}$, and ${ }^{68} \mathrm{Ga}$, with ${ }^{18} \mathrm{~F}$ being the most clinically utilized. SPECT radiotracers typically have longer physical half-life than most PET tracers; thus a central radiopharmaceutical laboratory can prepare radiotracers for delivery to SPECT facilities within a radius of several hundred miles. There are a range of radioisotopes (such as ${ }^{99 \mathrm{~m} T c},{ }^{201} \mathrm{Tl}$, ${ }^{67} \mathrm{Ga},{ }^{123} \mathrm{I}$, and ${ }^{111} \mathrm{In}$ ) that can be used for labeling SPECT 
radiopharmaceuticals, depending on the specific application. ${ }^{99} \mathrm{~m} \mathrm{Tc}$ is the most used radionuclide for nuclear medicine because it is readily available, relatively inexpensive, and gives lower radiation exposure [2-4].

A major advantage of nuclear medicine imaging is the extraordinarily high sensitivity: a typical PET scanner can detect between $10^{-11} \mathrm{~mol} / \mathrm{L}$ to $10^{-12} \mathrm{~mol} / \mathrm{L}$ concentrations, whereas MRI has a sensitivity of around $10^{-3} \mathrm{~mol} / \mathrm{L}$ to $10^{-5} \mathrm{~mol} / \mathrm{L}$ [4]. Because many molecules relevant to neuropsychiatric disorders are present at concentrations below $10^{-8} \mathrm{M}$, nuclear medicine imaging is currently the only available in vivo method capable of quantifying subtle cerebral pathophysiological changes that might occur before neurostructural abnormalities take place [5].

Radiotracers must fulfill several criteria to be successful for PET or SPECT imaging: including readily labeled with appropriate radionuclide and the labeled radiotracer being stable in vivo and nontoxic; sufficient affinity and high selectivity for the specific receptor combined with low nonspecific binding to brain tissue not containing the receptor of interest; rapid permeation through the bloodbrain barrier permitting high access of tracers to receptors, as well as allowing high initial brain uptake and fast clearance of the activity from the brain. A large number of radiotracers have been developed for brain imaging, but most of them were utilized only in vitro or in experimental animals and only few have the potentiality in clinical practice. Selective radiotracers are available for the study of dopaminergic, acetylcholinergic, serotonergic, and norepinephrine systems, as well as $\beta$-amyloid plaques with promising results $[5,6]$.

Dopamine is the most intensely studied monoaminergic neurotransmitter. Dopaminergic neurotransmission plays an important role in regulating several aspects of basic brain function, including motor, behavior, motivation, and working memory, and is involved in the pathogenesis of several psychiatric and neurological disorders. Degeneration of the nigrostriatal dopamine system causes Parkinson's disease (PD) and related Parkinsonism. Postsynaptic receptors may be involved in neurodegenerative disorders; they are functionally changed in Parkinsonism. Dopamine is thought to be involved in drug abuse. Most drugs of abuse, with the exception of benzodiazepines, have a direct effect on increasing the dopamine reward cycle in the brain. Abnormalities within the dopamine system in the brain play a major role in the pathophysiology of attention deficit hyperactivity disorder (ADHD). Dopamine receptors also play an important role in schizophrenia and the effect of neuroleptics is through blockage of dopamine $D_{2}$ receptors [6]. Neuroimaging techniques permit us to quantify dopaminergic activity in the living human brain, which has become increasingly part of the assessment and diagnosis of neuropsychiatric disorders. To date, there are numerous PET and SPECT radiotracers available for targeting different steps in the process of dopaminergic neurotransmission. This paper will concentrate on the radiotracers that have been developed for imaging dopaminergic neurons, describe their unique strengths and limitations in the assessment of neuropsychiatric disorders, and suggest future directions in the diagnosis and management of neuropsychiatric disorders.

\section{Radiotracers for Imaging Dopaminergic Neurons}

Diagnosis of neurological and psychiatric disorders associated with disturbances of dopaminergic functioning can be challenging, especially in the early stages. The evolution of neuroimaging technique over the past decade has yielded unprecedented information about dopaminergic neurons. PET and SPECT techniques have been successfully employed to visualize the activity of dopamine synthesis, reuptake sites, and receptors (Table 1). The Chemical structure of various radiotracers for the assessment of dopamine system is illustrated on Figure 1. DOPA decarboxylase activity and dopamine turnover can both be measured with ${ }^{18} \mathrm{~F}$ DOPA or ${ }^{18}$ F-FMT PET [7]. ${ }^{18}$ F-DOPA PET was the first neuroimaging technique validated for the assessment of presynaptic dopaminergic integrity. The uptake of ${ }^{18} \mathrm{~F}$-DOPA reflects both the density of the axonal terminal plexus and the activity of the striatal aromatic amino acid decarboxylase (AADC), the enzyme responsible for the conversion of ${ }^{18} \mathrm{~F}$ DOPA to ${ }^{18} \mathrm{~F}$-dopamine. However, AADC is present in the terminals of all monoaminergic neurons, measurements of ${ }^{18} \mathrm{~F}$-DOPA uptake into extrastriatal areas provides an index of the density of the serotonergic, norepinephrinergic, and dopaminergic terminals [8-10].

Dopamine transporter (DAT) is a protein complex located in presynaptic dopaminergic nerve terminals, which serves as the primary means for removing dopamine from the synaptic cleft. The availability of presynaptic DAT can be assessed with various radiotracers, which are typically tropane based $[7,11]$. Several PET tracers $\left({ }^{11} \mathrm{C}-\mathrm{CFT},{ }^{18} \mathrm{~F}-\right.$ CFT, ${ }^{18} \mathrm{~F}-\mathrm{FP}-\mathrm{CIT}$, and $\left.{ }^{11} \mathrm{C}-\mathrm{PE} 2 \mathrm{I}\right)$ and SPECT tracers such as ${ }^{123}$ I- $\beta$-CIT (Dopascan), ${ }^{123}$ I-FP-CIT (ioflupane, DaTSCAN), ${ }^{123} \mathrm{I}$-altropane, ${ }^{123} \mathrm{I}$-IPT, ${ }^{123} \mathrm{I}$-PE2I, and ${ }^{99 \mathrm{~m}} \mathrm{Tc}$-TRODAT-1 are now available to measure DAT availability $[8,11-$ 17]. ${ }^{123}$ I- $\beta$-CIT was the first widely applied SPECT tracer in imaging DAT, however, the lack of specificity is a disadvantage. This radiotracer binds not only to DAT but also to norepinephrine transporter (NET) and serotonin transporter (SERT). Another disadvantage of ${ }^{123} \mathrm{I}-\beta$-CIT is considered not convenient for routine out-patient evaluations since adequate imaging should be performed 20$30 \mathrm{~h}$ following the injection [11]. The faster kinetics of ${ }^{123} \mathrm{I}-$ FP-CIT is a clear advantage for clinical use, which allows adequate acquisition as early as $3 \mathrm{~h}$ following injection [18]. Conversely, ${ }^{123}$ I-altropane SPECT images have been less extensively investigated and are more difficult to quantify owing to rapid wash out from the brain [19]. The technetium based ${ }^{99 \mathrm{~m}}$ Tc-TRODAT-1 has the advantage of being relatively inexpensive and available in kit form. The easy preparation of ${ }^{99 \mathrm{~m}}$ Tc-TRODAT-1 from lyophilized kits could be an ideal agent for daily clinical application [16]. However, its specific signal is lower than the ${ }^{123} \mathrm{I}$-based SPECT tracers. To date, only DaTSCAN ( ${ }^{123} \mathrm{I}$-FP-CIT) and ${ }^{99 \mathrm{~m}} \mathrm{Tc}$-TRODAT1 are commercially available in the market and licensed for detecting loss of functional dopaminergic neuron terminals in the striatum.

In the brain, dopamine activates the five known types of dopamine receptors $-\mathrm{D}_{1}, \mathrm{D}_{2}, \mathrm{D}_{3}, \mathrm{D}_{4}$, and $\mathrm{D}_{5}$. Dopamine 
TABLE 1: Radiotracers available for targeting different steps in the process of dopaminergic neurotransmission and clinical applications.

\begin{tabular}{|c|c|c|c|}
\hline Targeting & Tracer & Chemical name & Clinical studies (references) \\
\hline \multirow{2}{*}{$\begin{array}{l}\text { Dopamine } \\
\text { synthesis and turn } \\
\text { over }\end{array}$} & ${ }^{18} \mathrm{~F}-\mathrm{DOPA}$ & L-3,4-dihydroxy-6-[ $\left[{ }^{18} \mathrm{~F}\right]$-fluorophenylalanine & $\begin{array}{l}\text { PD [11, 20-23], gene therapy for PD [24-26], } \\
\text { ADHD [27], schizophrenia }[28,29]\end{array}$ \\
\hline & ${ }^{18} \mathrm{~F}-\mathrm{FMT}$ & $\mathrm{O}-\left[{ }^{18} \mathrm{~F}\right]$-fluoromethyl-D-tyrosine & Gene therapy for PD $[30,31]$ \\
\hline \multirow{7}{*}{$\begin{array}{l}\text { Dopamine } \\
\text { transporter }\end{array}$} & ${ }^{11} \mathrm{C}-\mathrm{CFT}$ & {$\left[{ }^{11} \mathrm{C}\right]-2 \beta$-carbomethoxy-3$\beta$-ltropane } & Heroin abuse [32] \\
\hline & ${ }^{11} \mathrm{C}$-altropane & $\begin{array}{l}2 \beta \text {-carbomethoxy-3 } \beta \text { - }(4 \text {-fluorophenyl)-N- } \\
\text { ((E)-3-iodo-prop-2-enyl)tropane }\end{array}$ & ADHD [33] \\
\hline & $\begin{array}{l}{ }^{123} \mathrm{I}-\beta \text {-CIT } \\
\text { (Dopascan) }\end{array}$ & $\begin{array}{l}{\left[{ }^{123} \mathrm{I}\right]-(1 \mathrm{R})-2-\beta \text {-carbomethoxy-3- } \beta-(4-} \\
\text { iodophenyl)-tropane }\end{array}$ & $\begin{array}{l}\mathrm{PD}[11,20], \mathrm{PM}[34], \mathrm{PD} \& \mathrm{ET}[35] \text {, cocaine } \\
\text { abuse }[36,37], \mathrm{ADHD}[38]\end{array}$ \\
\hline & $\begin{array}{l}{ }^{123} \text { I-FP-CIT } \\
\text { (DaTSCAN) }\end{array}$ & $\begin{array}{l}{\left[{ }^{123} \mathrm{I}\right] \mathrm{N} \text { - } \omega \text {-fluoropropyl-2} \beta \text {-carbomethoxy- } 3 \beta \text { - }} \\
\text { (4-iodophenyl) } \\
\text { nortropane }\end{array}$ & $\begin{array}{l}\text { PM [39-41], PM \& ET [42], PD \& DLB [43], AD, } \\
\text { PD \& DLB [44], ADHD [45-47], schizophrenia } \\
{[48]}\end{array}$ \\
\hline & ${ }^{99 \mathrm{~m}}$ Tc-TRODAT-1 & $\begin{array}{l}\left.{ }^{[99 \mathrm{~m}} \mathrm{Tc}\right] \text { technetium }[2-[[2-[[[3-(4- \\
\text { chlorophenyl)-8-methyl-8-azabicyclo } \\
[3.2 .1] \text { oct-2-yl }]- \text { methyl }](2- \\
\text { mercaptoethyl)amino]-ethyl]amino] ethane- } \\
\text { thiolato(3-)-N2,N2',S2,S2'] oxo-[1R-(exo- } \\
\text { exo)] }\end{array}$ & $\begin{array}{l}\text { PD }[23,49-51], \text { MSA }[52], \text { PM \& VP }[53], \text { DRD } \\
{[54], \text { PSP }[55] \text {, genetic study of PD }[51,56],} \\
\text { genetic study of MJD [57], cocaine abuse }[58] \text {, } \\
\text { opiate abuse [59], nicotine dependence }[60,61] \\
\text { ADHD [62-68] }\end{array}$ \\
\hline & ${ }^{123}$ I-altropane & $\begin{array}{l}{\left[{ }^{123} \mathrm{I}\right]-2 \beta \text {-carbomethoxy-3} \beta \text {-(4-fluorophenyl)- }} \\
\mathrm{N} \text {-(1-iodoprop-1-en-3-yl) } \\
\text { ortropane }\end{array}$ & $\mathrm{PD}[21], \mathrm{ADHD}[69]$ \\
\hline & ${ }^{123} \mathrm{I}-\mathrm{IPT}$ & $\begin{array}{l}{\left[{ }^{123} \mathrm{I}\right]-\mathrm{N} \text {-(3-iodopropen-2-yl)-2- }} \\
\text { carbomethoxy-3beta-(4-chlorophenyl) } \\
\text { tropane }\end{array}$ & ADHD [70] \\
\hline \multirow[t]{2}{*}{$\begin{array}{l}\text { Dopamine } \mathrm{D}_{1} \\
\text { receptor }\end{array}$} & ${ }^{11} \mathrm{C}-\mathrm{NNC} 112$ & $\begin{array}{l}\text { (+)-5-(7-Benzofuranyl)-8-chloro-7-hydroxy- } \\
\text { 3-methyl-2,3,4,5-tetrahydro-1H-3- } \\
\text { benzazepine }\end{array}$ & Schizophrenia [71] \\
\hline & ${ }^{11} \mathrm{C}-\mathrm{SCH} 23390$ & $\begin{array}{l}\text { (R)-(+)-8-Chloro-2,3,4,5-tetrahydro-3- } \\
{\left[{ }^{11} \mathrm{C}\right] \text { methyl-5-phenyl-1H-3-benzazepin-7-ol }}\end{array}$ & Schizophrenia $[72,73]$ \\
\hline \multirow[t]{2}{*}{$\begin{array}{l}\text { Dopamine } \mathrm{D}_{2} \\
\text { receptor }\end{array}$} & ${ }^{11}$ C-Raclopride & $\begin{array}{l}\text { 3,5-dichloro-N- }\{[(2 S)-1 \text {-ethylpyrrolidin-2- } \\
\text { yl]methyl }\}-2 \text {-hydroxy-6- } \\
{\left[{ }^{11} \mathrm{C}\right] \text { methoxybenzamide }}\end{array}$ & $\begin{array}{l}\text { Drug abuse }[74-79] \text { cocaine abuse }[80,81] \text {, } \\
\text { methamphetamine abuse }[82] \text {, opiate abuse }[83] \text {, } \\
\text { alcohol dependence }[84], \text { ADHD }[85,86] \text {, } \\
\text { antipsychotics }[48,87-89]\end{array}$ \\
\hline & ${ }^{123} \mathrm{I}-\mathrm{IBZM}$ & $\begin{array}{l}\left.\text { (S)-(-)-3-[ }{ }^{123} \mathrm{I}\right] \text { iodo-2-hydroxy-6-methoxy-N- } \\
{[(1 \text {-ethyl-2-pyrrolidinyl)methyl] benzamide }}\end{array}$ & $\begin{array}{l}\text { PM }[40,41], \text { schizophrenia }[90] \text {, antipsychotics } \\
{[89,91,92]}\end{array}$ \\
\hline \multirow{2}{*}{$\begin{array}{l}\text { vesicular } \\
\text { monoamine } \\
\text { transporter type-2 }\end{array}$} & ${ }^{11} \mathrm{C}-\mathrm{DTBZ}$ & $( \pm)-\alpha-\left[{ }^{11} \mathrm{C}\right]$ dihydrotetrabenazine & $\mathrm{PD}[7,11,20]$ \\
\hline & $\begin{array}{l}{ }^{18} \text { F-FP-DTBZ } \\
(\text { AV-133) }\end{array}$ & 9- $\left[{ }^{18} \mathrm{~F}\right]$ fluoropropyl-(+)-dihydrotetrabenazine & $\mathrm{PD}[93], \mathrm{DLB} \& \mathrm{AD}[94]$ \\
\hline
\end{tabular}

Abbreviations: Parkinson's disease (PD), Parkinsonism (PM), multiple-system atrophy (MSA), progressive supranuclear palsy (PSP), essential tremor (ET), vascular Parkinsonism (VP), Machado-Joseph disease (MJD), DOPA-responsive dystonia (DRD), dementia with Lewy bodies disease (DLB), Alzheimer's disease $(\mathrm{AD})$, and attention deficit hyperactivity disorder (ADHD).

receptors belong to the G-protein-coupled superfamily. The dopamine $\mathrm{D}_{1}$ and $\mathrm{D}_{5}$ receptor subtypes are known as $\mathrm{D}_{1}$-like receptors and couple to inhibitory G-proteins, whereas the dopamine $\mathrm{D}_{2}, \mathrm{D}_{3}, \mathrm{D}_{4}$ receptor subtypes are known as $\mathrm{D}_{2}$-like family and couple to stimulatory G-proteins. Only dopamine $\mathrm{D}_{1}$ and $\mathrm{D}_{2}$ receptors have been imaged in humans. For dopamine $\mathrm{D}_{1}$ subtype, the most commonly used radiotracers are ${ }^{11} \mathrm{C}-\mathrm{SCH} 23390$ and ${ }^{11} \mathrm{C}-\mathrm{NNC112}$ [7]. As assessment of $\mathrm{D}_{1}$-like receptors has not gained clinical significance; therefore many investigations have focused on the $\mathrm{D}_{2}$-like receptor system in the past. Dopamine $\mathrm{D}_{2}$ receptors are assessed most commonly with the use of benzamide radiotracers. ${ }^{11} \mathrm{C}$-raclopride, ${ }^{18} \mathrm{~F}$-spiperone, and ${ }^{18} \mathrm{~F}$-methyl-benperidol have been developed for PET imaging; alternatively, ${ }^{123} \mathrm{I}-$ IBZM ( ${ }^{123} \mathrm{I}$-iodobenzamide), ${ }^{123} \mathrm{I}$-epidrpride, and ${ }^{123} \mathrm{I}$-IBF have been developed for SPECT imaging. ${ }^{11} \mathrm{C}$-raclopride is currently the gold standard PET tracer for dopamine $\mathrm{D}_{2}$ receptors. In contrast to ${ }^{11} \mathrm{C}$-raclopride, with a physical halflife of approximately $20 \mathrm{~min},{ }^{123} \mathrm{I}$-IBZM allows shipment over considerable distances since the radiotracer has a longer physical half-life of $13.2 \mathrm{~h}[95,96] .{ }^{123} \mathrm{I}$-epidrpride, displaying very high affinity to $\mathrm{D}_{2} / \mathrm{D}_{3}$ receptors, has been exploited for quantification and visualization of low density extrastriatal $\mathrm{D}_{2} / \mathrm{D}_{3}$ receptors [97].

The vesicular monoamine transporter type 2 (VMAT2) is expressed by all monoaminergic neurons and serves to pump monoamines from cytosol into synaptic vesicles thereby protecting the neurotransmitters from catabolism by cytosolic enzymes and packaging them for subsequent exocytotic release [98]. In striatum, more than $95 \%$ of 
<smiles>NC(Cc1cc(O)c(O)cc1F)C(=O)O</smiles><smiles>NC(Cc1cc(O)ccc1F)C(=O)O</smiles>

(a) Dopamine synthesis<smiles>COC(=O)[C@H]1C2CCC(C[C@@H]2c2ccc(F)cc2)N1C</smiles>

${ }^{18} \mathrm{~F}-\beta-\mathrm{CFT}$

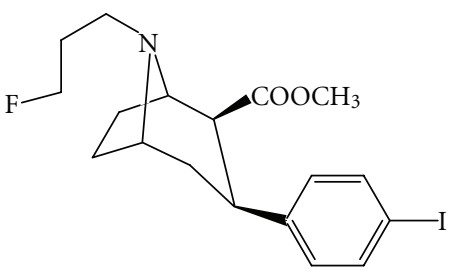

${ }^{123}$ I-FP-CIT (DaTSCAN)<smiles>COC(=O)[C@H]1C[C@@H]2CC[C@H](C1)N2C</smiles>

${ }^{123} \mathrm{I}-\beta$-CIT

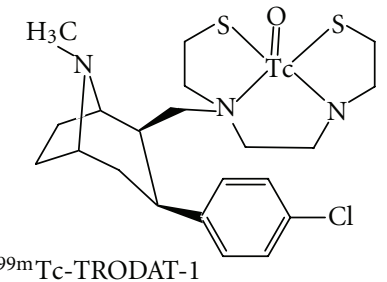

99m Tc-TRODAT-1<smiles>COC(=O)[C@@H]1C[C@H]2CC[C@@H]1N2C/C=C/I</smiles>

${ }^{123}$ I-Altropane

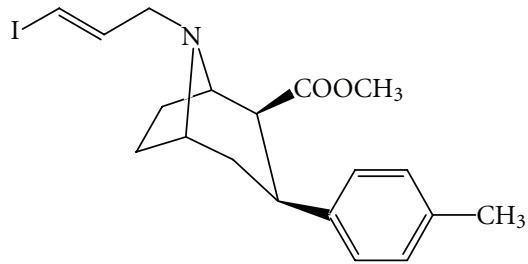

${ }^{123}$ I-PE2I

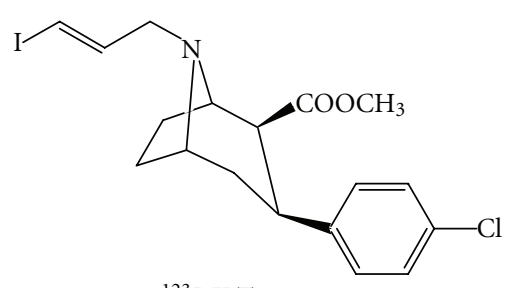

${ }^{123} \mathrm{I}$-IPT

(b) Dopamine transporter<smiles>CN1CCc2cc(Cl)c(O)cc2[C@H](c2ccccc2)C1</smiles>

${ }^{11} \mathrm{C}-\mathrm{SCH}-23390$<smiles>CN1CCc2cc(Cl)c(O)cc2[C@H](c2cccc3c2OCC3)C1</smiles>

${ }^{11} \mathrm{C}-\mathrm{NNC} 112$

(c) Dopamine $\mathrm{D}_{1}$ receptor<smiles>CCC1CCC[C@]1(C)CNC(=O)c1c(O)c(Cl)cc(Cl)c1OC</smiles>

${ }^{11} \mathrm{C}$-raclopride<smiles>O=C(CCCN1CCC2(CC1)C(=O)N(CCF)CN2c1ccccc1)c1ccc(F)cc1</smiles>

${ }^{18} \mathrm{~F}$-spiperone<smiles>CCN1CCC[C@H]1CNC(=O)c1c(OC)ccc(I)c1O</smiles>

${ }^{123}$ I-IBZM<smiles></smiles>

${ }^{123}$ I-IBF<smiles>CCN1CCCC1CNC(=O)c1cc(I)cc(OC)c1OC</smiles>

${ }^{123}$ I-epidepride
$\mathrm{H}_{3} \mathrm{C}-$<smiles>Cn1c(=O)n(C2CCN(CCCC(=O)c3ccc(F)cc3)CC2)c2ccccc21</smiles>

${ }^{18} \mathrm{~F}$-methyl-benperidol

(d) Dopamine $\mathrm{D}_{2}$ receptor

FIgure 1: Continued. 

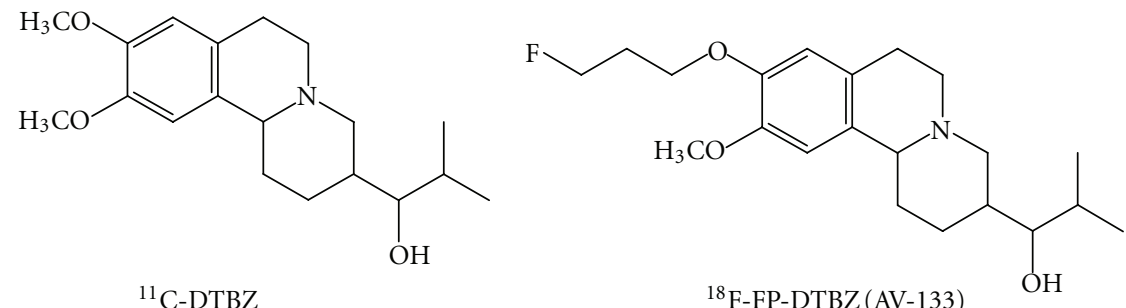

(e) Vesicular monoamine transporter type 2 (VMAT2)

FIGURE 1: Chemical structure of various radiotracers for the assessment of dopamine synthesis, reuptake sites, and receptors.

VMAT2 is associated with dopaminergic terminals and VAMT2 concentration linearly reflects to the concentration of dopamine in the striatum $[20,99]$. The most widely used radiotracer is $\left[{ }^{11} \mathrm{C}\right]$ dihydrotetrabenazine (DTBZ), which binds specifically and reversibly to VMAT2 and is amenable to quantification of striatal, diencephalic, and brain stem neurons and terminals with PET [98]. The ${ }^{18} \mathrm{~F}$-labeled VAMT2 tracer, ${ }^{18}$ F-FP-DTBZ (AV-133), has been developed with the advantage of having a half-life of nearly $2 \mathrm{~h}$, which allows shipment of tracers over considerable distances to PET centers without an on-site cyclotron $[93,100]$.

\section{Parkinson's Disease and Other Movement Disorders}

Parkinson's disease, the second most common neurodegenerative disorder, is characterized by severe loss of dopamine neurons, resulting in a deficiency of dopamine $[101,102]$. Clinical diagnosis of Parkinson's disease relies on the presence of characteristic motor symptoms, including bradykinesia, rigidity and resting tremors, but the rate of misdiagnosis of Parkinson's disease using this method was as high as $24 \%$ according to previous studies [103-105]. Good response to dopaminergic drugs, particularly levodopa, is often used to support the clinical diagnosis of Parkinson's disease. However, some patients with pathologically confirmed Parkinson's disease have a poor response to levodopa; conversely, some patients with early multiple-system atrophy (MSA) or progressive supranuclear palsy (PSP) have beneficial responses to drug treatment [106]. Since the introduction of in vivo molecular imaging techniques, the diagnosis of Parkinson's disease became more reliable by assessing dopaminergic and even nondopaminergic systems [107].

Imaging of striatal denervation in Parkinson's disease was first reported with ${ }^{18} \mathrm{~F}$-DOPA PET and has been extended in imaging studies of DAT and VMAT2 [11, 13, 14, 21-23, 34, $39,49,94,98,108]$. All these markers demonstrate reduced uptake in the striatum, the location of the presynaptic nigral dopamine terminal projections. More specifically, these imaging studies in Parkinson's disease patients have shown the nigral neuron loss is asymmetric, where the putamenal reductions are more profound than those in caudate [10]. Studies with ${ }^{18} \mathrm{~F}-\mathrm{DOPA}$ and DAT tracers indicated a reduction in radiotracer uptake of approximately $50-70 \%$ in the putamen in Parkinson's disease subjects $[21,34,39,49]$. In general, all these DAT markers show similar findings in Parkinson's disease to those seen with ${ }^{18} \mathrm{~F}$ DOPA PET and are able to differentiate early Parkinson's disease from normal subjects with a sensitivity of around $90 \%[6,50]$. A multicenter phase III trial conducted at Institute of Nuclear Energy Research (INER) in Taiwan indicated that patients with Parkinson's disease were easily distinguished from healthy volunteers with ${ }^{99 \mathrm{~m}} \mathrm{Tc}$-TRODAT1 SPECT, which had a sensitivity of $97.2 \%$ and a specificity of $92.6 \%$ (unpublished data).

${ }^{18} \mathrm{~F}$-DOPA PET is considered as a standard procedure for evaluating dopaminergic metabolism. However, use of ${ }^{18} \mathrm{~F}$-DOPA PET may sometimes overestimate the nigral cell reserve in Parkinson's disease, since it may show a better than actual uptake due to compensatory increased activity of dopa decarboxylase that occurs with dopamine cell terminal loss [11]. On the contrary, the striatal uptake of DAT radiotracers in early Parkinson's disease may overestimate the reduction in terminal density due to the relative downregulation of DAT in the remaining neurons as a response to nigral neuron loss, a compensatory mechanism that acts to maintain synaptic dopamine levels [23]. Additionally, DAT activity falls with age in healthy subjects, but striatal ${ }^{18} \mathrm{~F}$-DOPA uptake does not appear to be age dependent $[8,9,22]$.

The signs and symptoms present in early Parkinson's disease can resemble those of many other movement disorders, particularly other forms of parkinsonism such as progressive supranuclear palsy, progressive supranuclear palsy, druginduced Parkinsonism (DIP), vascular Parkinsonism (VP), dementia with Lewy bodies (DLB), and essential tremor (ET) $[10,40]$. It is important to discriminate between idiopathic Parkinson's disease (IPD) and other neurodegenerative Parkinsonian syndromes because there are marked differences in the prognoses and therapies.

Neuroimaging studies indicate that the pattern of dopaminergic neurons loss in Parkinsonian syndromes is less region-specific than in idiopathic Parkinson's disease, the putamen and caudate are more equally effected. Moreover, left and right striatal radiotracer uptake in these disorders is also more symmetric than in idiopathic Parkinson's disease [10]. Lu et al. found DAT imaging with ${ }^{99 \mathrm{~m} T c-T R O D A T-}$ 1 probably could provide important information to differentiate progressive supranuclear palsy from Parkinson's 


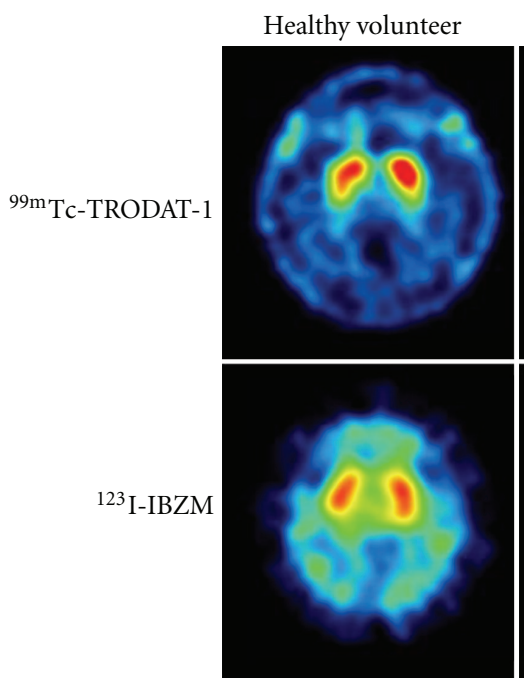

Parkinson's disease

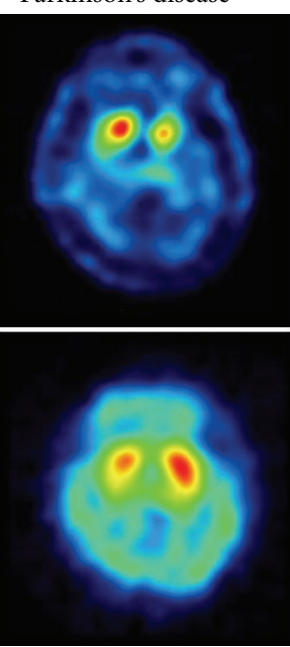

MSA

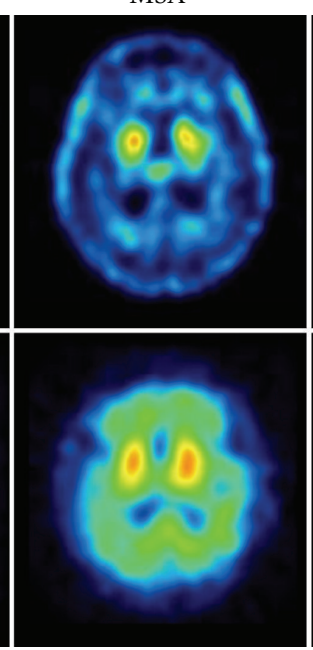

PSP

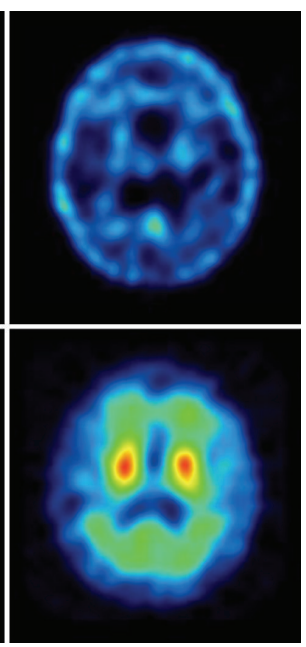

FIGURE 2: Dopamine transporter (DAT) imaging with ${ }^{99 \mathrm{~m}} \mathrm{Tc}-\mathrm{TRODAT}-1$ and dopamine $\mathrm{D}_{2}$ receptor imaging with ${ }^{123} \mathrm{I}-\mathrm{IBZM}$ of healthy volunteer and patients with Parkinson's disease (PD), multiple-system atrophy (MSA), and progressive supranuclear palsy (PSP). The striatal DAT uptakes were significantly decreased in patients with PD, MSA, and PSP, whereas the dopamine $\mathrm{D}_{2}$ receptor uptakes were mildly decreased in patients with PD, MSA, and PSP.

disease. The striatal binding was more symmetrically reduced in patients with progressive supranuclear palsy, in contrast to the greater asymmetric reduction in the Parkinson's disease groups [52]. Essential tremor is a condition most commonly misdiagnosed with Parkinson's disease; up to $25 \%$ of cases are initially diagnosed as having Parkinson's disease. DAT imaging using ${ }^{123} \mathrm{I}-\beta$-CIT and ${ }^{123} \mathrm{I}$-FPCIT SPECT has been successfully proven in differentiating essential tremor from Parkinson's disease; subjects with essential tremor have normal levels of striatal uptake. Such studies have found the sensitivity and specificity for clinical diagnosis of distinguishing Parkinson's disease from essential tremor to be $95 \%$ and $93 \%$, respectively [35, 42]. Vascular Parkinsonism is a disorder caused by cerebrovascular disease and accounts for 4.4-12\% of all cases of Parkinsonism [109]. Dopaminergic imaging studies may help with the diagnosis of vascular Parkinsonism, although studies have provided conflicting results. Two studies (using ${ }^{123} \mathrm{I}-\beta$-CIT or ${ }^{99 \mathrm{~m}} \mathrm{Tc}-$ TRODAT-1 SPECT) found near normal DAT binding in patients with vascular Parkinsonism, differentiating them from patients with Parkinson's disease, whereas other studies have found reduced DAT binding in some patients with vascular Parkinsonism [19, 34, 53]. Dementia with Lewy bodies, characterized by severe nigrostriatal dopaminergic neuron degeneration, is the second most common form of degenerative dementia (after Alzheimer's disease, AD). Accurate diagnosis in Alzheimer's disease and dementia with Lewy bodies is particularly important in the early stage of the disease for the treatment and management of the patient. ${ }^{18} \mathrm{~F}$-DOPA, DAT, and VMAT2 markers can differentiate dementia with Lewy bodies, who display lower striatal binding in the putamen, caudate, and midbrain, from those with Alzheimer's disease, who have normal striatal binding similar to those observed in healthy controls. Mean sensitivity of ${ }^{123}$ I-FP-CIT scans for a clinical diagnosis of probable dementia with Lewy bodies was $77.7 \%$, while the mean specificity for excluding non-Lewy body dementia was $90.4 \%$, giving overall diagnostic accuracy of $85.7 \%[19,43$, $44,94]$. In addition, a DAT study with $99 \mathrm{~m} \mathrm{Tc}-\mathrm{TRODAT}-$ 1 scan in DOPA-responsive dystonia (DRD) patients, a hereditary progressive disorder with sustained response to low-dosage levodopa but entirely different prognosis from Parkinson's disease, showed significant higher DAT uptake in patients with DOPA -responsive dystonia than those in patients with young onset Parkinson disease $(P<0.001)$, suggesting a normal nigrostriatal presynaptic dopaminergic terminal in DOPA -responsive dystonia [54].

Higher diagnostic accuracy in the differential diagnosis of Parkinsonism may be achieved by combining pre- and postsynaptic quantitative information about the dopaminergic system. Previous imaging studies with the most commonly used dopamine $\mathrm{D}_{2}$ receptor tracers, ${ }^{11} \mathrm{C}$ raclopride and ${ }^{123} \mathrm{I}$-IBZM, have shown that the uptake of DAT are downregulated in patients with early idiopathic Parkinson's disease, but $\mathrm{D}_{2}$ receptors are comparable to normal subjects in medicated Parkinson's disease patients and may even be mildly increased in unmedicated patients. With the progression of Parkinson's disease, striatal $\mathrm{D}_{2}$ receptor activity returns to normal or may fall below normal levels [98]. In contrast to Parkinson's disease, patients with atypical Parkinsonism like progressive supranuclear palsy or progressive supranuclear palsy typically show reductions in both DAT and $\mathrm{D}_{2}$ binding $[7,40,41]$. Figure 2 illustrates the DAT scans with ${ }^{99 \mathrm{~m}} \mathrm{Tc}$-TRODAT- 1 and the $\mathrm{D}_{2}$ receptor scans with ${ }^{123}$ I-IBZM of healthy volunteer and patients with Parkinson's disease, multiple system atrophy, and progressive supranuclear palsy. However, the small differences in $\mathrm{D}_{2}$ binding failed to discriminate between idiopathic Parkinson's disease, nonidiopathic Parkinson's disease, and healthy control groups, according to a report of 
a multicenter phase III trial conducted by INER (unpublished data). Nevertheless, the dopamine $\mathrm{D}_{2}$ receptor imaging is successfully demonstrated in differentiation of the subtypes of progressive supranuclear palsy: Richardson's syndrome (RS) and progressive supranuclear palsyparkinsonism (PSP-P). Assessment of pre- and postsynaptic dopaminergic activities in Richardson's syndrome, PSP-P, or idiopathic Parkinson's disease with ${ }^{99 m}$ Tc-TRODAT-1 and ${ }^{123}$ I-IBZM images showed that the activities of $\mathrm{D}_{2}$ receptor were reduced in Richardson's syndrome but not in PSP$\mathrm{P}(P<0.01)$, which was consistent with the clinical manifestation of PSP-P group with better prognosis and levodopa responsiveness than that of RS patients [55].

Imaging the distribution and density of single molecules in the living brain will give us straightforward information of the genetic linkages among different aspects of Parkinsonism. Genetic studies have identified at least 9 genes with mutation that cause $10 \%$ to $15 \%$ of Parkinson's disease cases [103]. SNCA, Parkin, PINK1, DJ-1, LRRK2, and ATP13A2 have been identified to be the causative genes for familial and early onset Parkinson's disease (EOPD) [51]. A ${ }^{99 \mathrm{~m} T c-T R O D A T-}$ 1 scan revealed that patients with the PINK1 mutation displayed a rather even, symmetrical reduction of dopamine uptake, whereas patients with late-onset Parkinson's disease (LOPD) displayed a dominant decline in dopamine uptake in the putamen [56]. The contribution of genetic variants in ATP13A2 to Parkinson's disease of Taiwanese patients was investigated with ${ }^{99 \mathrm{~m}} \mathrm{Tc}$-TRODAT-1 SPECT, showing that the striatal uptake of patients carrying the variants of G1014S and A746T were similar to that of idiopathic Parkinson's disease [51]. In addition, ${ }^{99 \mathrm{~m}} \mathrm{Tc}$-TRODAT-1 SPECT was exploited to examine the DAT activity in Machado-Joseph disease (MJD) patients and gene carriers, showing that the DAT concentration was significantly reduced in patients with Machado-Joseph disease and in asymptomatic gene carriers compared to those of healthy volunteers $(P<0.001)$ [57].

Molecular imaging is also a major tool for the evaluation of new experimental therapeutic strategies in Parkinson's disease. Cell transplantation to replace lost neurons is a recent approach to the treatment of progressive neurodegenerative diseases. Transplantation of human embryonic dopamine neurons into the brains of patients with Parkinson's disease has proved beneficial in open clinical trials $[7,24]$. Several teams of investigators have reported the results from double-blind placebo-controlled trials of human embryonic dopaminergic tissue transplantation for the treatment of Parkinson's disease. Evaluations with ${ }^{18} \mathrm{~F}$-DOPA scans have shown that significant declines in the motor scores over time after transplantation $(P<0.001)$, based on the Unified Parkinson Disease Rating Scale (UPDRS), were associated with increases in putamen ${ }^{18} \mathrm{~F}$-DOPA uptake at 4 years posttransplantation followups $(P<0.001)$. Furthermore, posttransplantation changes in putamen PET signals and clinical outcomes were significantly intercorrelated $(P<$ $0.02)[24,25]$. Gene therapy may be potentially useful for ameliorating the motor symptoms of Parkinson's disease. Several gene therapy studies in humans investigated transductions (with various viral vectors) of glial-derived neurotrophic factor (GDNF), neurturin (NTN), AADC, or glutamic acid decarboxylase (GAD). Brain imaging with ${ }^{18} \mathrm{~F}$-DODA or ${ }^{18} \mathrm{~F}$-FMT PET has been exploited to evaluate clinical outcomes adjunct to the UPDRS scores [26, 30, 31, 110-112].

\section{Drug Abuse and Addicted Brain}

Dopamine is the neurotransmitter that has been classically associated with the reinforcing effects of drug abuse. This notion reflects the fact that most of the drugs of abuse increase extracellular dopamine concentration in limbic regions including nucleus accumbens (NAc). The involvement of dopamine in drug reinforcement is well recognized but its role in drug addiction is much less clear. Imaging studies have provided evidences of how the human brain changes as an individual becomes addicted [74-77].

Cocaine is considered one of the most reinforcing drug of abuse; therefore, this drug has been extensively investigated the associated reinforcing effects in humans. Cocaine is believed to work by blocking the DAT and thereby increasing the availability of free dopamine within the brain. The relationship between DAT blockage and the reinforcement effects of cocaine abuser has been assessed with ${ }^{11} \mathrm{C}$-cocaine PET, showing that intravenous cocaine at doses commonly abused by human $(0.3-0.6 \mathrm{mg} / \mathrm{kg})$ blocked between 60 to $77 \%$ of DAT sites in these subjects. Moreover, the magnitude of the self-reported "high" was positively correlated with the degree of DAT occupancy, and at least $47 \%$ of the transporters had to be blocked for subjects to perceive cocaine's effects [80]. When compared to normal controls, cocaine abusers showed significant decreases in dopamine $\mathrm{D}_{2}$ receptor availability that persisted 3-4 months after detoxification. Decreases in dopamine $\mathrm{D}_{2}$ receptor availability were associated with decreased metabolism in several regions of the frontal lobes, most markedly in orbitofrontal cortex and cingulate gyri [81]. PET studies with ${ }^{11} \mathrm{C}-$ raclopride have consistently shown that subjects with a wide variety of drug addictions (cocaine, heroin, alcohol, and methamphetamine) have significant reductions in dopamine $\mathrm{D}_{2}$ receptor availability in the striatum that persist months after protracted detoxification $[76,78,82-84,113]$.

Since dopamine $\mathrm{D}_{2}$ receptors are involved in the response to reinforcing properties of natural as well as drug stimuli, it has been postulated that reduced $\mathrm{D}_{2}$ receptor levels in drug-addicted subjects would make them less sensitive to natural reinforcers. Volkow et al. compared the function of the dopamine system of 20 cocaine-dependent subjects with 23 controls using ${ }^{11} \mathrm{C}$-raclopride PET by measuring the relative changes in extracellular dopamine induced by intravenous methylphenidate. Cocaine-dependent subjects showed reduced dopamine release in the striatum and also had a reduced "high" relative to controls, indicating that methylphenidate-induced striatal dopamine increased in cocaine abusers were significantly blunted when compared with those of controls [74, 113].

Despite the similarities between cocaine and methylphenidate in their affinity to the DAT, cocaine is much more abused than methylphenidate. Using ${ }^{11} \mathrm{C}$ labeled cocaine and methylphenidate for PET imaging, it has 
been demonstrated that the regional distribution of ${ }^{11} \mathrm{C}$ methylphenidate was identical to that of ${ }^{11} \mathrm{C}$-cocaine and they competed with each other for the same binding site. However, these two drugs differed markedly in their pharmacokinetics. Both drugs entered the brain rapidly after intravenous administration (in less than $10 \mathrm{~min}$ ) while the rate of clearance of ${ }^{11} \mathrm{C}$-methylphenidate from striatum (90 min) was significantly slower than that of ${ }^{11} \mathrm{C}$-cocaine (20 min). Therefore, it is postulated that the initial uptake of these stimulant drugs into the brain, not their steadystate presence, is necessary for drug-induced reinforcement $[76,114]$.

In addition to differences in bioavailability, the route of administration significantly affects the effects of stimulant drugs presumably via its effects on pharmacokinetics. This is particularly relevant to methylphenidate because it is abused when taken intravenously but rarely so when taken orally. Volkow et al. measured the dopamine changes induced by oral and intravenous administration of methylphenidate that produce equivalent DAT occupancy (about 70\%). Even though the dopamine increases were comparable for oral and intravenous (approximately $20 \%$ changes in specific binding of ${ }^{11} \mathrm{C}$-raclopride in striatum), oral methylphenidate did not induce significant increases in self-reports of "high." Intravenous administration of methylphenidate leads to fast dopamine changes, whereas oral administration increases dopamine slowly. The failure to observe the "high" with oral methylphenidate is likely to reflect the slower pharmacokinetics $[76,77,85]$.

A view of DAT regulation in cocaine addicts may improve our understanding of clinical aspects of cocaine dependence, including drug-induced carving, dysphoria, and relapse. The DAT levels in the brain of cocaine-dependence were measured by ${ }^{99 \mathrm{~m}} \mathrm{Tc}$-TRODAT-1 SPECT. It has shown that there were significantly higher DAT levels in cocaine-dependent subjects compared to controls for the anterior putamen, posterior putamen, and caudate. DAT levels in these regions were $10 \%, 17 \%$, and $8 \%$ higher in the cocaine dependent subjects compared to controls. This study also showed that ${ }^{99 m}$ Tc-TRODAT-1 uptake was negatively correlated with the duration of time since last use of cocaine [58]. Malison et al. examined the striatal DAT levels in 28 cocaine-abusing subjects with ${ }^{123} \mathrm{I}-\beta$-CIT SPECT and found that striatal DAT levels were significantly increased (approximately 20\%) in acutely abstinent cocaine-abusing subjects (96h or less) [36]. Another study using ${ }^{123}$ I- $\beta$-CIT SPECT also showed approximately a $14 \%$ increase in DAT availability in acutely abstinent (3.7 days on average) cocaine subjects compared to controls [37].

Human imaging studies suggest that preexisting differences in dopamine circuits may be one mechanism underlying the variability in responsiveness to drug abuse. In particular, baseline measures of striatal dopamine $\mathrm{D}_{2}$ receptors in nonaddicted subjects have been shown to predict subjective responses to the reinforcing effects of intravenous methylphenidate treatment. Individuals describing the experience as pleasant had substantially lower levels of dopamine $\mathrm{D}_{2}$ receptors compared with those describing methylphenidate as unpleasant $[74,79]$.
Methadone maintenance treatment has been demonstrated to be effective in reducing or eliminating opioid drug use. Despite its therapeutic effectiveness, relatively little is known about neuronal adaptations in the brains of methadone users. A PET study with ${ }^{11} \mathrm{C}$-CFT has documented reduced DAT availability in patients with prolonged abstinence and with methadone maintenance treatment. Furthermore, the subjects with methadone maintenance treatment showed significant decreases of DAT uptake function in the bilateral putamen in comparison to the prolonged abstinence subjects [32]. Another study examined the differences between opioid-dependent users treated with a very low dose of methadone or undergoing methadonefree abstinence. The striatal DAT availability was significantly reduced in low-dose methadone users $(0.78 \pm 0.27)$ and methadone-free abstinence $(0.94 \pm 0.28)$ compared to controls $(1.16 \pm 0.26)$, which has demonstrated that methadone treatment or abstinence can benefit the recovery of impaired dopamine neurons. Moreover, lower midbrain SERT availability also was noted in methadone maintenance treatment and methadone-free abstinence groups, which implicated deregulation of serotoninergic neurons in opioid abuse [59].

The behavioral and neurobiological effects of tobacco smoking, in which nicotine may play an import role, are similar to those of addictive drugs. The pre- and postsynaptic activity of dopamine neuron was examined in male smokers with ${ }^{99 \mathrm{~m}} \mathrm{Tc}$-TRODAT- $1 /{ }^{123} \mathrm{I}$-IBZM SPECT. A decrease in DAT availability was found in the striatum of male smokers $(P<0.05)$, suggesting cigarette smoking may alter central dopamine functions, particularly at the presynaptic sites. Moreover, the total FTND (Fagerström Test for Nicotine Dependence) scores correlated negatively with striatal DAT availability in male smokers, but not with striatal $\mathrm{D}_{2}$ bindings [60].

\section{Attention Deficit Hyperactivity Disorder}

Attention deficit hyperactivity disorder (ADHD) is a common disorder of childhood characterized by inattention, excessive motor activity, impulsiveness, and distractibility. It is associated with serious disability in children, adolescents and adults. There is converging evidence that abnormalities within the dopamine system in the brain play a major role in the pathophysiology of ADHD [33, 62, 63]. Despite extensive investigation of the neuropathophysiology of ADHD by a wide array of methodologies, the mechanism underlying this disorder is still unknown.

Neuroimaging holds promise for unveiling the neurobiological causes of ADHD and provides invaluable information for management of the disease. Ernst et al. investigated the integrity of presynaptic dopaminergic function in children with ADHD through the use of ${ }^{18} \mathrm{~F}-\mathrm{DOPA}$ PET and found a $48 \%$ increase in DOPA decarboxylase activation in the right midbrain in ADHD children compared with normal controls [27].

Methylphenidate is considered as a first-line medication for ADHD in children and adults $[86,115]$. This medicine 
is very effective for the treatment of $\mathrm{ADHD}$; it is estimated that $60-70 \%$ of ADHD subjects have favorable responses. Volkow et al. utilized ${ }^{11} \mathrm{C}$-cocaine and ${ }^{11} \mathrm{C}$-raclopride PET to assess the DAT and dopamine $\mathrm{D}_{2}$ receptor occupancy for a given dose of methylphenidate. It has been proven that this drug significantly blocked DAT $(60 \pm 11 \%)$ and increased synaptic dopamine levels $(16 \pm 8 \%)$ reduction in ${ }^{11} \mathrm{C}$-raclopride binding in the striatum [86].

It is widely accepted that the therapeutic effects of methylphenidate are through the blocking of DAT; therefore, it seems appropriate to investigate the DAT availability in patients with ADHD. The first DAT imaging study was conducted in 6 adults with ADHD by using ${ }^{123}$ I-altropane SPECT, showing that the DAT levels in unmedicated patients were approximately $70 \%$ higher than those in controls [69]. However, following studies with a variety of DAT markers have shown a much smaller increase even not reaching statistical significance than that found in the first study with ${ }^{123}$ I-altropane $[38,45,64,65,70]$. Dresel et al. investigated DAT binding in 17 treatment naïve adults with ADHD compared with 10 age- and gender-matched control subjects by using ${ }^{99 \mathrm{~m}} \mathrm{Tc}$-TRODAT-1 SPECT. Patients with ADHD exhibited a significantly increased specific DAT binding in the striatum (average 17\%) compared with normal subjects $(P<0.01)$ [64]. Furthermore, Krause et al. examined DAT binding in an expanded sample of 31 adults with ADHD and 15 control subjects; the earlier findings of greater DAT binding in adults with ADHD was replicated [62]. DAT density has been compared in 9 treatment naïve children with ADHD and 6 normal children using ${ }^{123}$ I-IPT SPECT, showing that mean DAT binding in the basal ganglia was significantly increased with $40 \%$ on the left and $51 \%$ on the right side compared with the controls [70]. By using ${ }^{11} \mathrm{C}-$ altropane PET, a highly selective radiotracer and technically superior imaging modality, Spencer et al. found that the overall DAT binding was increased $28 \%$ in adults with ADHD compared with controls [33]. However, the ${ }^{123} \mathrm{I}-\beta-$ CIT SPECT study showed no significant difference in striatal density between adult patients with ADHD and normal controls [38]. Furthermore, Hesse et al. found the striatal DAT binding ratio (specific to nondisplaceable binding) was significantly reduced in treatment naïve adults with ADHD by using ${ }^{123}$ I-FP-CIT SPECT (ADHD: $5.18 \pm 0.98$; control: $6.36 \pm 1.34$ ) [46]. The cause of divergent findings might be the clinical heterogeneity of the ADHD phenotype rather than differences in imaging technology, applied tracer type, or outcome measurement method.

It has been shown that methylphenidate lowers DAT availability very effectively in normal subjects and in patients with ADHD. After treatment with methylphenidate $(5 \mathrm{mg}$ t.i.d), the specific DAT binding decreased (average 29\%) significantly in all patients $(P<0.01)$, investigated by ${ }^{99 \mathrm{~m}} \mathrm{Tc}-$ TRODAT-1 SPECT [64]. Vles et al. examined DAT binding in 6 treatment naïve boys with ADHD (aged 6-10 years), using ${ }^{123} \mathrm{I}$-FP-CIT SPECT. Three months after treatment with methylphenidate, a $28-75 \%$ decrease of DAT binding in the striatum was found [47]. Generally nonresponse to methylphenidate is known to occur in approximately $30 \%$ of patients with ADHD, which may be caused by lower baseline
DAT availability in these patients. Krause et al. assessed the relationship between DAT availability and treatment outcome using ${ }^{99 \mathrm{~m}} \mathrm{Tc}$-TRODAT-1 SPECT. It has shown that ADHD patients with poor response to methylphenidate had a low primary DAT availability, whereas most of patients with high DAT availability exhibited good clinical response to methylphenidate $[66,67]$.

Previous studies have confirmed the reduction of DAT availability by nicotine $[60,61]$. Patients with ADHD and with a history of nicotine abuse displayed lower DAT availability than nonsmokers with ADHD. DAT seems to be elevated in nonsmoking ADHD patients suffering from the purely inattentive subtype of ADHD as well as in those with the combined or purely hyperactive/impulsive subtype $[63,68]$.

\section{Schizophrenia and the Effects of Antipsychotics}

Schizophrenia is a chronic mental illness characterized by disturbances of thoughts, perceptions, volition, and cognition. Manifestations of the illness are commonly divided into positive (delusions, hallucinations, thought disorganization, paranoia), negative (lack of drive and motivation, alogia, social withdrawal), and cognitive symptoms (poor performance on cognitive tasks involving attention and working memory). Positive symptoms are considered to be a result of the increased subcortical release of dopamine causing greater stimulation of $\mathrm{D}_{2}$ receptors. The negative and cognitive symptoms are thought to arise from reduced $\mathrm{D}_{1}$ receptor stimulation $[28,90,116]$.

With the advance of brain imaging techniques, direct evidence suggestive of dysregulation of dopaminergic transmission in schizophrenia has emerged. Several lines of study have documented an increase in the striatal accumulation of ${ }^{18} \mathrm{~F}$ DOPA or ${ }^{11} \mathrm{C}$-DOPA in patients with schizophrenia, which is consistent with increased activity of DOPA decarboxylase, an enzyme involved in dopamine synthesis $[28,90]$. More recently, Howes et al. assessed striatal dopaminergic function in patients with prodromal schizophrenia using ${ }^{18} \mathrm{~F}$-DOPA PET and found elevated striatal ${ }^{18} \mathrm{~F}-\mathrm{DOPA}$ uptake, which gradually reached the level in those with schizophrenia. In addition, increased striatal ${ }^{18} \mathrm{~F}$-DOPA uptake was correlated with the severity of prodromal psychopathologic and neuropsychological impairment [29].

Since the primary target of many antipsychotic drugs is antagonism at striatal $\mathrm{D}_{2}$ receptors, Abi-Dargham et al. compared striatal $\mathrm{D}_{2}$ receptor availability before and during pharmacologically induced acute dopamine depletion with ${ }^{123}$ I-IBZM SPECT in 18 untreated patients and 18 controls. At baselines, no difference has been found between these 2 groups. However, after depletion of endogenous dopamine, $\mathrm{D}_{2}$ receptor availability was significantly higher in patients with schizophrenia compared with controls $(P<0.01)$. In addition, the study suggests elevated synaptic dopamine is predictive of good treatment response of positive symptoms to antipsychotic drugs [90].

PET studies with ${ }^{11} \mathrm{C}-\mathrm{SCH} 2390$ or ${ }^{11} \mathrm{C}-\mathrm{NNC} 112$ in drug naïve schizophrenia patients have reported divergent 
findings in $\mathrm{D}_{1}$ receptor binding and cognitive functioning. Some studies have shown a decrease in prefrontal $D_{1}$ receptor binding [72], whereas others have shown an increase in $\mathrm{D}_{1}$ receptor binding [71] or reported no differences between patients and controls [73]. A few have shown a relationship between $\mathrm{D}_{1}$ dysfunction and working memory performance in treatment naïve patients. The variability in the results was possibly influenced by parameters of the particular patient populations including duration of illness, symptoms and medications.

Nuclear medicine imaging technique has been widely used for the drug development in recent years. There are several approaches such as microdosing, measurement of in vivo receptor occupancy, and biomarkers [117]. Most imaging studies in the past have concentrated on antipsychotics. Several lines of research indicate the efficacy of antipsychotics to be related to their capacity to antagonize dopamine. Brain Imaging with PET or SPECT allows determination of dopamine $\mathrm{D}_{2}$ receptor occupancy rate in the human brain during treatment with antipsychotics, which are associated with extrapyramidal symptoms (EPS) of antipsychotic drugs [118]. Farde et al. found that the classical antipsychotics occupied $60-85 \%$ of striatal dopamine $\mathrm{D}_{2}$ receptor was necessary for treating positive symptoms of schizophrenia, as measured by ${ }^{11} \mathrm{C}$-raclopride PET imaging. However, $\mathrm{D}_{2}$ receptor occupancies above $80 \%$ were associated with a significantly higher risk of extrapyramidal symptoms [87, $118,119]$.

Several new antipsychotics have been introduced to market with lower affinity for dopamine $\mathrm{D}_{2}$ receptors, for which the term "atypical antipsychotics" had been coined. Atypical antipsychotics display with a low or nonexistent propensity of extrapyramidal symptoms as compared to classical neuroleptics [88].

Therapeutic concentrations reported from clinical studies have been confirmed by $\mathrm{D}_{2}$ receptor imaging for classical antipsychotics and a number of atypical antipsychotics (i.e., amisulpride, clozapine, olanzapine, quetiapine, risperidone, sertindole, and zotepine). From available studies, the atypical antipsychotics clozapine and quetiapine appear to have the lowest striatal $\mathrm{D}_{2}$ receptor occupancy rates and the typical antipsychotic haloperidol has the highest. Risperidone, sertindole, and zotepine hold an intermediate position. The incidence of EPS ranged from none with clozapine, olanzapine, quetiapine, to $80 \%$ of patients treated with haloperidol $[89,91,92,120]$. The effect of DAT on a neuroleptic was examined by ${ }^{123} \mathrm{I}$-FP-CIT SPECT. Mateos and coworkers found in schizophrenic patients 4 weeks of treatment with risperidone did not influence striatal DAT binding ratios significantly [48].

\section{Conclusions}

With the appropriate radiotracers, neuroimaging enables the visualization of the presynaptic and postsynaptic sites in the dopaminergic system. Imaging these markers provides key insights into the pathophysiology of Parkinson's disease and related neurodegenerative diseases and it becomes an important endpoint in clinical trials of potential diseasemodifying therapy for Parkinson's disease such as gene therapy or cell replacement therapy. The availability of easy-to-apply diagnostic procedures such as metabolic and DAT imaging is encouraging. Nonetheless, it should also be emphasized that these results are no replacement for thorough clinical investigation. Future studies are needed in the development of new radiotracers to target nondopaminergic brain pathways and the glial reaction to disease.

Neuroimaging studies have provided evidences of how the human brain changes as an individual becomes addicted. Although available studies have mostly focused on dopamine, the interaction of dopamine with other neurotransmitters such as GABA, glutamate, and serotonin plays an important role in modulating the magnitude of the dopamine responses to drugs.

At this time, knowledge from DAT imaging studies in patients with ADHD is limited by the use of various radiotracers and small sample size. In the future, measurements of DAT with PET or SPECT should be performed in greater collectives, allowing the assignment to different subtypes of ADHD. Of further interest will be whether the DAT availability has a prognostic value for the treatment response of methylphenidate. Furthermore, since methylphenidate exerts its therapeutic efficacy is through blocking DAT and NET, the role of norepinephrinergic system in the pathophysiology of ADHD will become increasing important as the recently available of NET radiotracers.

The clinically most important contribution from neuroimaging on $\mathrm{D}_{2}$ receptor occupancy in patients with schizophrenia is probably the identification of the optimal therapeutic window for antipsychotic drugs. Based on this concept, the striatal $\mathrm{D}_{2}$ receptors binding profiles of typical and atypical antipsychotic agents has been determined.

In the future, the role of neuroimaging may become more significant in guiding therapy. Enhancements in image resolution and specific molecular tags will permit accurate diagnoses of a wide range of diseases, based on both structural and molecular changes in the brain. For widespread application, advances in molecular imaging should include the characterization of new radiotracers, application of modeling techniques, standardization and automation of imageprocessing techniques, and appropriate clinical settings in large multicenter trials. The growing field of neuroimaging is helping nuclear medicine physicians identify pathways into personalized patient care.

\section{Acknowledgments}

The authors are indebted to the research teams of Chang Gung Memorial Hospital, Tri-Service General Hospital, National Cheng Kung University Hospital, and Taipei Veterans General Hospital for carrying out the clinical studies for the neuroimaging agents developed at Institute of Nuclear Energy Research. The development of neuroimaging agents was partially supported by the Grant from National Science Council (NSC99-3111-Y-042A-013). 


\section{References}

[1] D. F. Wong, G. Gründer, and J. R. Brasic, "Brain imaging research: does the science serve clinical practice?" International Review of Psychiatry, vol. 19, no. 5, pp. 541-558, 2007.

[2] F. A. Metter and M. J. Guiberteau, "Radioactivity, radionuclides, and radiopharmaceuticals," in Essentials of Nuclear Medicine Imaging, chapter 1, pp. 1-13, Saunders, Elsevier, 5th edition, 2006.

[3] F. A. Metter and M. J. Guiberteau, "Positron emission tomography (PET) imaging," in Essentials of Nuclear Medicine Imaging, chapter 13, pp. 359-423, Saunders, Elsevier, 5th edition, 2006.

[4] R. Weissleder and U. Mahmood, "Molecular imaging," Radiology, vol. 219, no. 2, pp. 316-333, 2001.

[5] M. Fumita and R. B. Innis, Neuropsychopharmacology: The Fifth Generation of Progress, Lippincott Williams \& Wilkins, Philadelphia, Pa, USA, 1st edition, 2002.

[6] W. D. Heiss and K. Herholz, "Brain receptor imaging," Journal of Nuclear Medicine, vol. 47, no. 2, pp. 302-312, 2006.

[7] C. Sioka, A. Fotopoulos, and A. P. Kyritsis, "Recent advances in PET imaging for evaluation of Parkinson's disease," European Journal of Nuclear Medicine and Molecular Imaging, vol. 37, no. 8, pp. 1594-1603, 2010.

[8] N. Pavese and D. J. Brooks, "Imaging neurodegeneration in Parkinson's disease," Biochimica et Biophysica Acta, vol. 1792, no. 7, pp. 722-729, 2009.

[9] N. Pavese, L. Kiferle, and P. Piccini, "Neuroprotection and imaging studies in Parkinson's disease," Parkinsonism and Related Disorders, vol. 15, supplement 4, pp. S33-S37, 2010.

[10] J. P. Seibyl, "Imaging studies in movement disorders," Seminars in Nuclear Medicine, vol. 33, no. 2, pp. 105-113, 2003.

[11] D. J. Brooks, K. A. Frey, K. L. Marek et al., "Assessment of neuroimaging techniques as biomarkers of the progression of Parkinson's disease," Experimental Neurology, vol. 184, supplement 1, pp. S68-S79, 2003.

[12] J. O. Rinne, A. Laihinen, K. Någren, H. Ruottinen, U. Ruotsalainen, and U. K. Rinne, "PET examination of the monoamine transporter with $\left[{ }^{11} \mathrm{C}\right] \beta$-CIT and $\left[{ }^{11} \mathrm{C}\right] \beta$-CFT in early Parkinson's disease," Synapse, vol. 21, no. 2, pp. 97-103, 1995.

[13] J. O. Rinne, H. Ruottinen, J. Bergman, M. Haaparanta, P. Sonninen, and O. Solin, "Usefulness of a dopamine transporter PET ligand $\left[{ }^{18} \mathrm{~F}\right] \beta$-CFT in assessing disability in Parkinson's disease," Journal of Neurology Neurosurgery and Psychiatry, vol. 67, no. 6, pp. 737-741, 1999.

[14] J. O. Rinne, E. Nurmi, H. M. Ruottinen, J. Bergman, O. Eskola, and O. Solin, "[ $\left.{ }^{18} \mathrm{~F}\right] \mathrm{FDOPA}$ and $\left[{ }^{18} \mathrm{~F}\right] \mathrm{CFT}$ are both sensitive PET markers to detect presynaptic dopaminergic hypofunction in early Parkinson's disease," Synapse, vol. 40, no. 3, pp. 193-200, 2001.

[15] S. K. Meegalla, K. Plössl, M. P. Kung et al., "Synthesis and characterization of technetium-99m-labeled tropanes as dopamine transporter-imaging agents," Journal of Medicinal Chemistry, vol. 40, no. 1, pp. 9-17, 1997.

[16] M. P. Kung, D. A. Stevenson, K. Plössl et al., "[ ${ }^{99 m}$ Tc]TRODAT-1: a novel technetium-99m complex as a dopamine transporter imaging agent," European Journal of Nuclear Medicine, vol. 24, no. 4, pp. 372-380, 1997.

[17] M. J. Ribeiro, M. Vidailhet, C. Loc'h et al., "Dopaminergic function and dopamine transporter binding assessed with positron emission tomography in Parkinson disease," Archives of Neurology, vol. 59, no. 4, pp. 580-586, 2002.
[18] J. Booij, G. Tissingh, A. Winogrodzka et al., "Practical benefit of $\left[{ }^{123} \mathrm{I}\right] \mathrm{FP}-\mathrm{CIT}$ SPET in the demonstration of the dopaminergic deficit in Parkinson's disease," European Journal of Nuclear Medicine, vol. 24, no. 1, pp. 68-71, 1997.

[19] J. L. Cummings, C. Henchcliffe, S. Schaier, T. Simuni, A. Waxman, and P. Kemp, "The role of dopaminergic imaging in patients with symptoms of dopaminergic system neurodegeneration," Brain, vol. 134, no. 11, pp. 3146-3166, 2011.

[20] B. Ravina, D. Eidelberg, J. E. Ahlskog et al., "The role of radiotracer imaging in Parkinson disease," Neurology, vol. 64, no. 2, pp. 208-215, 2005.

[21] H. H. Fernandez, J. H. Friedman, A. J. Fischman, R. B. Noto, and M. C. Lannon, "Is altropane SPECT more sensitive to fluoroDOPA PET for detecting early Parkinson's disease?” Medical Science Monitor, vol. 7, no. 6, pp. 1339-1343, 2001.

[22] E. Nurmi, H. M. Ruottinen, J. Bergman et al., "Rate of progression in Parkinson's disease: a $6-\left[{ }^{18} \mathrm{~F}\right]$ fluoro-L-dopa PET study," Movement Disorders, vol. 16, no. 4, pp. 608-615, 2001.

[23] W. S. Huang, Y. H. Chiang, J. C. Lin, Y. H. Chou, C. Y. Cheng, and R. S. Liu, "Crossover study of ${ }^{99 m}$ Tc-TRODAT-1 SPECT and ${ }^{18} \mathrm{~F}$-FDOPA PET in Parkinson's disease patients," Journal of Nuclear Medicine, vol. 44, no. 7, pp. 999-1005, 2003.

[24] C. R. Freed, P. E. Greene, R. E. Breeze et al., "Transplantation of embryonic dopamine neurons for severe Parkinson's disease," New England Journal of Medicine, vol. 344, no. 10, pp. 710-719, 2001.

[25] Y. Ma, C. Tang, T. Chaly et al., "Dopamine cell implantation in Parkinson's disease: long-term clinical and ${ }^{18} \mathrm{~F}$-FDOPA PET outcomes," Journal of Nuclear Medicine, vol. 51, no. 1, pp. 7-15, 2010.

[26] W. J. Marks Jr., J. L. Ostrem, L. Verhagen et al., "Safety and tolerability of intraputaminal delivery of CERE-120 (adeno-associated virus serotype 2-neurturin) to patients with idiopathic Parkinson's disease: an open-label, phase I trial," The Lancet Neurology, vol. 7, no. 5, pp. 400-408, 2008.

[27] M. Ernst, A. J. Zametkin, J. A. Matochik, D. Pascualvaca, P. H. Jons, and R. M. Cohen, "High midbrain $\left[{ }^{18} \mathrm{~F}\right] \mathrm{DOPA}$ accumulation in children with attention deficit hyperactivity disorder," American Journal of Psychiatry, vol. 156, no. 8, pp. 1209-1215, 1999.

[28] N. H. Patel, N. S. Vyas, B. K. Puri, K. S. Nijran, and A. AlNahhas, "Positron emission tomography in schizophrenia: a new perspective," Journal of Nuclear Medicine, vol. 51, no. 4, pp. 511-520, 2010.

[29] O. D. Howes, A. J. Montgomery, M. C. Asselin et al., "Elevated striatal dopamine function linked to prodromal signs of schizophenia," Archives of General Psychiatry, vol. 66, no. 1, pp. 13-20, 2009.

[30] J. L. Eberling, W. J. Jagust, C. W. Christine et al., "Results from a phase I safety trial of $h A A D C$ gene therapy for Parkinson disease," Neurology, vol. 70, no. 21, pp. 1980-1983, 2008.

[31] S. I. Muramatsu, K. I. Fujimoto, S. Kato et al., "A phase I study of aromatic l-amino acid decarboxylase gene therapy for Parkinson's disease," Molecular Therapy, vol. 18, no. 9, pp. 1731-1735, 2010.

[32] J. Shi, L. Y. Zhao, M. L. Copersino et al., "PET imaging of dopamine transporter and drug craving during methadone maintenance treatment and after prolonged abstinence in heroin users," European Journal of Pharmacology, vol. 579, no. 1-3, pp. 160-166, 2008.

[33] T. J. Spencer, J. Biederman, B. K. Madras et al., "In vivo neuroreceptor imaging in attention-deficit/hyperactivity 
disorder: a focus on the dopamine transporter," Biological Psychiatry, vol. 57, no. 11, pp. 1293-1300, 2005.

[34] N. Quinn, "A multicenter assessment of dopamine transporter imaging with DOPASCAN/SPECT in parkinsonism," Neurology, vol. 57, no. 4, pp. 746-747, 2001.

[35] S. Asenbaum, W. Pirker, P. Angelberger, G. Bencsits, M. Pruckmayer, and T. Brucke, "[ $\left.{ }^{123} \mathrm{I}\right] \beta$-CIT and SPECT in essential tremor and Parkinson's disease," Journal of Neural Transmission, vol. 105, no. 10-12, pp. 1213-1228, 1998.

[36] R. T. Malison, S. E. Best, C. H. van Dyck et al., "Elevated striatal dopamine transporters during acute cocaine abstinence as measured by $\left[{ }^{123} \mathrm{I}\right] \beta$-CIT SPECT," American Journal of Psychiatry, vol. 155, no. 6, pp. 832-834, 1998.

[37] L. K. Jacobsen, J. K. Staley, R. T. Malison et al., "Elevated central serotonin transporter binding availability in acutely abstinent cocaine-dependent patients," American Journal of Psychiatry, vol. 157, no. 7, pp. 1134-1140, 2000.

[38] C. H. van Dyck, D. M. Quinlan, L. M. Cretella et al., "Unaltered dopamine transporter availability in adult attention deficit hyperactivity disorder," American Journal of Psychiatry, vol. 159, no. 2, pp. 309-312, 2002.

[39] J. Booij, J. D. Speelman, M. W. I. M. Horstink, and E. C. Wolters, "The clinical benefit of imaging striatal dopamine transporters with $\left[{ }^{123} \mathrm{I}\right] \mathrm{FP}-\mathrm{CIT}$ SPET in differentiating patients with presynaptic parkinsonism from those with other forms of parkinsonism," European Journal of Nuclear Medicine, vol. 28, no. 3, pp. 266-272, 2001.

[40] W. Koch, C. Hamann, P. E. Radau, and K. Tatsch, "Does combined imaging of the pre- and postsynaptic dopaminergic system increase the diagnostic accuracy in the differential diagnosis of parkinsonism?" European Journal of Nuclear Medicine and Molecular Imaging, vol. 34, no. 8, pp. 12651273, 2007.

[41] M. Plotkin, H. Amthauer, S. Klaffke et al., "Combined ${ }^{123} \mathrm{I}$-FP-CIT and ${ }^{123} \mathrm{I}$-IBZM SPECT for the diagnosis of parkinsonian syndromes: study on 72 patients," Journal of Neural Transmission, vol. 112, no. 5, pp. 677-692, 2005.

[42] T. S. Benamer, J. Patterson, D. G. Grosset et al., "Accurate differentiation of parkinsonism and essential tremor using visual assessment of $\left[{ }^{123} \mathrm{I}\right]$-FP-CIT SPECT imaging: the $\left.{ }^{[123} \mathrm{I}\right]$-FP-CIT study group," Movement Disorders, vol. 15, no. 3, pp. 503-510, 2000.

[43] S. Colloby and J. O'Brien, "Functional imaging in Parkinson's disease and dementia with Lewy bodies," Journal of Geriatric Psychiatry and Neurology, vol. 17, no. 3, pp. 158-163, 2004.

[44] J. T. O’Brien, S. Colloby, J. Fenwick et al., "Dopamine transporter loss visualized with FP-CIT SPECT in the differential diagnosis of dementia with lewy bodies," Archives of Neurology, vol. 61, no. 6, pp. 919-925, 2004.

[45] R. Larisch, W. Sitte, C. Antke et al., "Striatal dopamine transporter density in drug naive patients with attentiondeficit/hyperactivity disorder," Nuclear Medicine Communications, vol. 27, no. 3, pp. 267-270, 2006.

[46] S. Hesse, O. Ballaschke, H. Barthel, and O. Sabri, "Dopamine transporter imaging in adult patients with attentiondeficit/hyperactivity disorder," Psychiatry Research, vol. 171, no. 2, pp. 120-128, 2009.

[47] J. S. H. Vles, F. J. M. Feron, J. G. M. Hendriksen, J. Jolles, M. J. P. G. van Kroonenburgh, and W. E. J. Weber, "Methylphenidate down-regulates the dopamine receptor and transporter system in children with Attention Deficit Hyperkinetic Disorder (ADHD)," Neuropediatrics, vol. 34, no. 2, pp. 77-80, 2003.
[48] J. J. Mateos, F. Lomeña, E. Parellada et al., "Lower striatal dopamine transporter binding in neuroleptic-naive schizophrenic patients is not related to antipsychotic treatment but it suggests an illness trait," Psychopharmacology, vol. 191, no. 3, pp. 805-811, 2007.

[49] W. S. Huang, S. Z. Lin, J. C. Lin, S. P. Wey, G. Ting, and R. S. Liu, "Evaluation of early-stage Parkinson's disease with ${ }^{99 m}$ Tc-TRODAT-1 imaging," Journal of Nuclear Medicine, vol. 42, no. 9, pp. 1303-1308, 2001.

[50] Y. H. Weng, T. C. Yen, M. C. Chen et al., "Sensitivity and specificity of ${ }^{99 m}$ Tc-TRODAT-1 SPECT imaging in differentiating patients with idiopathic Parkinson's disease from healthy subjects," Journal of Nuclear Medicine, vol. 45, no. 3, pp. 393-401, 2004.

[51] C. M. Chen, C. H. Lin, H. F. Juan et al., "ATP13A2 variability in Taiwanese Parkinson's disease," American Journal of Medical Genetics B, vol. 156, no. 6, pp. 720-729, 2011.

[52] C. S. Lu, Y. H. Weng, M. C. Chen et al., " ${ }^{99 m}$ Tc-TRODAT1 imaging of multiple system atrophy," Journal of Nuclear Medicine, vol. 45, no. 1, pp. 49-55, 2004.

[53] K. Y. Tzen, C. S. Lu, T. C. Yen, S. P. Wey, and G. Ting, "Differential diagnosis of Parkinson's disease and vascular parkinsonism by ${ }^{99 m}$ Tc-TRODAT-1," Journal of Nuclear Medicine, vol. 42, no. 3, pp. 408-413, 2001.

[54] C. C. Huang, T. C. Yen, Y. H. Weng, and C. S. Lu, "Normal dopamine transporter binding in dopa responsive dystonia," Journal of Neurology, vol. 249, no. 8, pp. 1016-1020, 2002.

[55] W. Y. Lin, K. J. Lin, Y. H. Weng et al., "Preliminary studies of differential impairments of the dopaminergic system in subtypes of progressive supranuclear palsy," Nuclear Medicine Communications, vol. 31, no. 11, pp. 974-980, 2010.

[56] Y. H. Weng, Y. H. W. Chou, W. S. Wu et al., "PINK1 mutation in Taiwanese early-onset parkinsonism: clinical, genetic, and dopamine transporter studies," Journal of Neurology, vol. 254, no. 10, pp. 1347-1355, 2007.

[57] T. C. Yen, K. Y. Tzen, M. C. Chen et al., "Dopamine transporter concentration is reduced in asymptomatic MachadoJoseph disease gene carriers," Journal of Nuclear Medicine, vol. 43, no. 2, pp. 153-159, 2002.

[58] P. Crits-Christoph, A. Newberg, N. Wintering et al., "Dopamine transporter levels in cocaine dependent subjects.," Drug and Alcohol Dependence, vol. 98, no. 1-2, pp. 7076, 2008.

[59] T. L. Yeh, K. C. Chen, S. H. Lin et al., "Availability of dopamine and serotonin transporters in opioid-dependent users-a two-isotope SPECT study," Psychopharmacology, vol. 220, no. 1, pp. 55-64, 2012.

[60] Y. K. Yang, W. J. Yao, T. L. Yeh et al., "Decreased dopamine transporter availability in male smokers-a dual isotope SPECT study," Progress in Neuro-Psychopharmacology and Biological Psychiatry, vol. 32, no. 1, pp. 274-279, 2008.

[61] A. Newberg, C. Lerman, N. Wintering, K. Ploessl, and P. D. Mozley, "Dopamine transporter binding in smokers and nonsmokers," Clinical Nuclear Medicine, vol. 32, no. 6, pp. 452-455, 2007.

[62] K. H. Krause, S. H. Dresel, J. Krause, C. la Fougere, and M. Ackenheil, "The dopamine transporter and neuroimaging in attention deficit hyperactivity disorder," Neuroscience and Biobehavioral Reviews, vol. 27, no. 7, pp. 605-613, 2003.

[63] J. Krause, "SPECT and PET of the dopamine transporter in attention-deficit/hyperactivity disorder," Expert Review of Neurotherapeutics, vol. 8, no. 4, pp. 611-625, 2008.

[64] S. Dresel, J. Krause, K. H. Krause et al., "Attention deficit hyperactivity disorder: binding of [ $\left.{ }^{99 m} \mathrm{Tc}\right]$ TRODAT-1 to the 
dopamine transporter before and after methylphenidate treatment," European Journal of Nuclear Medicine, vol. 27, no. 10, pp. 1518-1524, 2000.

[65] K. H. Krause, S. H. Dresel, J. Krause, H. F. Kung, and K. Tatsch, "Increased striatal dopamine transporter in adult patients with attention deficit hyperactivity disorder: effects of methylphenidate as measured by single photon emission computed tomography," Neuroscience Letters, vol. 285, no. 2, pp. 107-110, 2000.

[66] J. Krause, C. la Fougere, K. H. Krause, M. Ackenheil, and S. H. Dresel, "Influence of striatal dopamine transporter availability on the response to methylphenidate in adult patients with ADHD," European Archives of Psychiatry and Clinical Neuroscience, vol. 255, no. 6, pp. 428-431, 2005.

[67] C. La Fougère, J. Krause, K. H. Krause et al., "Value of ${ }^{99 m}$ Tc-TRODAT-1 SPECT to predict clinical response to methylphenidate treatment in adults with attention deficit hyperactivity disorder," Nuclear Medicine Communications, vol. 27, no. 9, pp. 733-737, 2006.

[68] K. H. Krause, S. H. Dresel, J. Krause, H. F. Kung, K. Tatsch, and M. Ackenheil, "Stimulant-like action of nicotine on striatal dopamine transporter in the brain of adults with attention deficit hyperactivity disorder," International Journal of Neuropsychopharmacology, vol. 5, no. 2, pp. 111-113, 2002.

[69] D. D. Dougherty, A. A. Bonab, T. J. Spencer, S. L. Rauch, B. K. Madras, and A. J. Fischman, "Dopamine transporter density in patients with attention deficit hyperactivity disorder," The Lancet, vol. 354, no. 9196, pp. 2132-2133, 1999.

[70] K. A. Cheon, Y. H. Ryu, Y. K. Kim, K. Namkoong, C. H. Kim, and J. D. Lee, "Dopamine transporter density in the basal ganglia assessed with $\left.{ }^{123} \mathrm{I}\right] \mathrm{IPT}$ SPET in children with attention deficit hyperactivity disorder," European Journal of Nuclear Medicine and Molecular Imaging, vol. 30, no. 2, pp. 306-311, 2003.

[71] A. Abi-Dargham, O. Mawlawi, I. Lombardo et al., "Prefrontal dopamine D1 receptors and working memory in schizophrenia," Journal of Neuroscience, vol. 22, no. 9, pp. 3708-3719, 2002.

[72] Y. Okubo, T. Suhara, K. Suzuki et al., "Decreased prefrontal dopamine D1 receptors in schizophrenia revealed by PET," Nature, vol. 385, no. 6617, pp. 634-635, 1997.

[73] P. Karlsson, L. Farde, C. Halldin, and G. Sedvall, "PET study of D1 dopamine receptor binding in neuroleptic-naive patients with schizophrenia," American Journal of Psychiatry, vol. 159, no. 5, pp. 761-767, 2002.

[74] N. D. Volkow, J. S. Fowler, and G. J. Wang, "The addicted human brain viewed in the light of imaging studies: brain circuits and treatment strategies," Neuropharmacology, vol. 47, supplement 1, pp. S3-S13, 2004.

[75] N. D. Volkow, J. S. Fowler, G. J. Wang, J. M. Swanson, and F. Telang, "Dopamine in drug abuse and addiction: results of imaging studies and treatment implications," Archives of Neurology, vol. 64, no. 11, pp. 1575-1579, 2007.

[76] N. D. Volkow, J. S. Fowler, G. J. Wang, and J. M. Swanson, "Dopamine in drug abuse and addiction: results from imaging studies and treatment implications," Molecular Psychiatry, vol. 9, no. 6, pp. 557-569, 2004.

[77] N. D. Volkow, J. S. Fowler, G. J. Wang, R. Baler, and F. Telang, "Imaging dopamine's role in drug abuse and addiction," Neuropharmacology, vol. 56, supplement 1, pp. S3-S8, 2009.

[78] N. D. Volkow, G. J. Wang, J. S. Fowler et al., "Reinforcing effects of psychostimulants in humans are associated with increases in brain dopamine and occupancy of $\mathrm{D}_{2}$ receptors,"
Journal of Pharmacology and Experimental Therapeutics, vol. 291, no. 1, pp. 409-415, 1999.

[79] N. D. Volkow, G. J. Wang, J. S. Fowler et al., "Prediction of reinforcing responses to psychostimulants in humans by brain dopamine $\mathrm{D}_{2}$ receptor levels," American Journal of Psychiatry, vol. 156, no. 9, pp. 1440-1443, 1999.

[80] N. D. Volkow, G. J. Wang, M. W. Fischman et al., "Relationship between subjective effects of cocaine and dopamine transporter occupancy," Nature, vol. 386, no. 6627, pp. 827830, 1997.

[81] N. D. Volkow, J. S. Fowler, G. J. Wang et al., "Decreased dopamine $D_{2}$ receptor availability is associated with reduced frontal metabolism in cocaine abusers," Synapse, vol. 14, no. 2, pp. 169-177, 1993.

[82] N. D. Volkow, L. Chang, G. J. Wang et al., "Low level of brain dopamine $\mathrm{D}_{2}$ receptors in methamphetamine abusers: association with metabolism in the orbitofrontal cortex," American Journal of Psychiatry, vol. 158, no. 12, pp. 20152021, 2001.

[83] G. J. Wang, N. D. Volkow, J. S. Fowler et al., "Dopamine $\mathrm{D}_{2}$ receptor availability in opiate-dependent subjects before and after naloxone-precipitated withdrawal," Neuropsychopharmacology, vol. 16, no. 2, pp. 174-182, 1997.

[84] N. D. Volkow, G. J. Wang, J. S. Fowler et al., "Decreases in dopamine receptors but not in dopamine transporters in alcoholics," Alcoholism: Clinical and Experimental Research, vol. 20, no. 9, pp. 1594-1598, 1996.

[85] N. D. Volkow, G. Wang, J. S. Fowler et al., "Therapeutic doses of oral methylphenidate significantly increase extracellular dopamine in the human brain," The Journal of Neuroscience, vol. 21, no. 2, Article ID RC121, 2001.

[86] N. D. Volkow, G. J. Wang, J. S. Fowler et al., "Relationship between blockade of dopamine transporters by oral methylphenidate and the increases in extracellular dopamine: therapeutic implications," Synapse, vol. 43, no. 3, pp. 181-187, 2002.

[87] L. Farde, S. Pauli, H. Hall et al., "Stereoselective binding of $11 \mathrm{C}$-raclopride in living human brain - a search for extrastriatal central D-2 dopamine receptors by PET," Psychopharmacology, vol. 94, no. 4, pp. 471-478, 1988.

[88] M. Nord and L. Farde, "Antipsychotic occupancy of dopamine receptors in schizophrenia," CNS Neuroscience and Therapeutics, vol. 17, no. 2, pp. 97-103, 2011.

[89] S. Kasper, J. Tauscher, B. Küfferle, C. Barnas, L. Pezawas, and S. Quiner, "Dopamine- and serotonin-receptors in schizophrenia: results of imaging-studies and implicationsfor pharmacotherapy in schizophrenia," European Archives of Psychiatry and Clinical Neuroscience, vol. 249, supplement 4, pp. S83-S89, 1999.

[90] A. Abi-Dargham, J. Rodenhiser, D. Printz et al., "Increased baseline occupancy of $\mathrm{D}_{2}$ receptors by dopamine in schizophrenia," Proceedings of the National Academy of Sciences of the United States of America, vol. 97, no. 14, pp. 8104-8109, 2000.

[91] J. Tauscher, B. Küfferle, S. Asenbaum, S. TauscherWisniewski, and S. Kasper, "Striatal dopamine-2 receptor occupancy as measured with $\left[{ }^{123} \mathrm{I}\right]$ iodobenzamide and SPECT predicted the occurrence of EPS in patients treated with atypical antipsychotics and haloperidol," Psychopharmacology, vol. 162, no. 1, pp. 42-49, 2002.

[92] S. Kasper, J. Tauscher, E. Küfferle, B. Hesselmann, C. Barnas, and T. Brücke, "IBZM-SPECT imaging of dopamine $\mathrm{D}_{2}$ 
receptors with typical and atypical antipsychotics," European Psychiatry, vol. 13, supplement 1, pp. S9-S14, 1998.

[93] N. Okamura, V. L. Villemagne, J. Drago et al., "In vivo measurement of vesicular monoamine transporter type 2 density in Parkinson disease with ${ }^{18} \mathrm{~F}-\mathrm{AV}-133$," Journal of Nuclear Medicine, vol. 51, no. 2, pp. 223-228, 2010.

[94] V. L. Villemagne, N. Okamura, S. Pejoska et al., "In vivo assessment of vesicular monoamine transporter type 2 in dementia with lewy bodies and Alzheimer disease," Archives of Neurology, vol. 68, no. 7, pp. 905-912, 2011.

[95] H. F. Kung, Y. Z. Guo, J. Billings et al., "Preparation and biodistribution of ${ }^{125}$ I]IBZM: a potential CNS D-2 dopamine receptor imaging agent," International Journal of Radiation Applications and Instrumentation B, vol. 15, no. 2, pp. 195-201, 1988.

[96] H. F. Kung, S. Pan, M. P. Kung et al., "In vitro and in vivo evaluation of $\left[{ }^{123}\right.$ I]IBZM: a potential CNS D-2 dopamine receptor imaging agent," Journal of Nuclear Medicine, vol. 30, no. 1, pp. 88-92, 1989.

[97] L. H. Pinborg, C. Videbaek, M. Ziebell et al., " $\left.{ }^{123} \mathrm{I}\right]$ epidepride binding to cerebellar dopamine $\mathrm{D}_{2} / \mathrm{D}_{3}$ receptors is displaceable: implications for the use of cerebellum as a reference region," Neuroimage, vol. 34, no. 4, pp. 1450-1453, 2007.

[98] N. I. Bohnen and K. A. Frey, "Imaging of cholinergic and monoaminergic neurochemical changes in neurodegenerative disorders," Molecular Imaging and Biology, vol. 9, no. 4, pp. 243-257, 2007.

[99] W. Lu and M. E. Wolf, "Expression of dopamine transporter and vesicular monoamine transporter 2 mRNAs in rat midbrain after repeated amphetamine administration," Molecular Brain Research, vol. 49, no. 1-2, pp. 137-148, 1997.

[100] K. J. Lin, Y. H. Weng, S. P. Wey et al., "Whole-body biodistribution and radiation dosimetry of ${ }^{18} \mathrm{~F}-\mathrm{FP}-(+)$-DTBZ $\left({ }^{18} \mathrm{~F}-\right.$ $\mathrm{AV}-133)$ : a novel vesicular monoamine transporter 2 imaging agent," Journal of Nuclear Medicine, vol. 51, no. 9, pp. 14801485, 2010.

[101] D. J. Gelb, E. Oliver, and S. Gilman, "Diagnostic criteria for Parkinson disease," Archives of Neurology, vol. 56, no. 1, pp. 33-39, 1999.

[102] E. Tolosa, G. Wenning, and W. Poewe, "The diagnosis of Parkinson's disease," The Lancet Neurology, vol. 5, no. 1, pp. 75-86, 2006.

[103] R. Pahwa and K. E. Lyons, "Early diagnosis of Parkinson's disease: recommendations from diagnostic clinical guidelines," The American Journal of Managed Care, vol. 16, supplement 4, pp. S94-99, 2010.

[104] A. J. Hughes, S. E. Daniel, S. Blankson, and A. J. Lees, "A clinicopathologic study of 100 cases of Parkinson's disease," Archives of Neurology, vol. 50, no. 2, pp. 140-148, 1993.

[105] A. H. Rajput, B. Rozdilsky, and A. Rajput, "Accuracy of clinical diagnosis in Parkinsonism-a prospective study," Canadian Journal of Neurological Sciences, vol. 18, no. 3, pp. 275-278, 1991.

[106] A. Antonini, "Imaging for early differential diagnosis of parkinsonism," The Lancet Neurology, vol. 9, no. 2, pp. 130$131,2010$.

[107] A. C. Felicio, M. C. Shih, C. Godeiro-Junior, L. A. F. Andrade, R. A. Bressan, and H. B. Ferraz, "Molecular imaging studies in Parkinson disease reducing diagnostic uncertainty," Neurologist, vol. 15, no. 1, pp. 6-16, 2009.

[108] A. M. M. Vlaar, T. de Nijs, A. G. H. Kessels et al., "Diagnostic value of ${ }^{123} \mathrm{I}$-ioflupane and ${ }^{123} \mathrm{I}$ - iodobenzamide SPECT scans in 248 patients with Parkinsonian syndromes," European Neurology, vol. 59, no. 5, pp. 258-266, 2008.

[109] B. Thanvi, N. Lo, and T. Robinson, "Vascular parkinsonism-an important cause of parkinsonism in older people," Age and Ageing, vol. 34, no. 2, pp. 114-119, 2005.

[110] A. L. Berry and T. Foltynie, "Gene therapy: a viable therapeutic strategy for Parkinson's disease?” Journal of Neurology, vol. 258, no. 2, pp. 179-188, 2010.

[111] L. Leriche, T. Björklund, N. Breysse et al., "Positron emission tomography imaging demonstrates correlation between behavioral recovery and correction of dopamine neurotransmission after gene therapy," Journal of Neuroscience, vol. 29, no. 5, pp. 1544-1553, 2009.

[112] M. G. Kaplitt, A. Feigin, C. Tang et al., "Safety and tolerability of gene therapy with an adeno-associated virus (AAV) borne $G A D$ gene for Parkinson's disease: an open label, phase I trial," The Lancet, vol. 369, no. 9579, pp. 2097-2105, 2007.

[113] N. D. Volkow, G. J. Wang, J. S. Fowler et al., "Decreased striatal dopaminergic responsiveness in detoxified cocainedependent subjects," Nature, vol. 386, no. 6627, pp. 830-833, 1997.

[114] N. D. Volkow, Y. S. Ding, J. S. Fowler et al., "Is methylphenidate like cocaine? Studies on their pharmacokinetics and distribution in the human brain," Archives of General Psychiatry, vol. 52, no. 6, pp. 456-463, 1995.

[115] M. V. Solanto, "Neuropsychopharmacological mechanisms of stimulant drug action in attention-deficit hyperactivity disorder: a review and integration," Behavioural Brain Research, vol. 94, no. 1, pp. 127-152, 1998.

[116] A. Abi-Dargham, "Do we still believe in the dopamine hypothesis? New data bring new evidence," International Journal of Neuropsychopharmacology, vol. 7, supplement 1, pp. S1-S5, 2004.

[117] O. Langer and C. Halldin, "PET and SPET tracers for mapping the cardiac nervous system," European Journal of Nuclear Medicine, vol. 29, no. 3, pp. 416-434, 2002.

[118] A. Takano, "The application of PET technique for the development and evaluation of novel antipsychotics," Current Pharmaceutical Design, vol. 16, no. 3, pp. 371-377, 2010.

[119] C. Hiemke, "Therapeutic drug monitoring in neuropsychopharmacology: does it hold its promises?" European Archives of Psychiatry and Clinical Neuroscience, vol. 258, supplement 1, pp. S21-S27, 2008.

[120] S. Kapur, R. Zipursky, C. Jones, G. Remington, and S. Houle, "Relationship between dopamine $\mathrm{D}_{2}$ occupancy, clinical response, and side effects: a double-blind PET study of firstepisode schizophrenia," American Journal of Psychiatry, vol. 157, no. 4, pp. 514-520, 2000. 


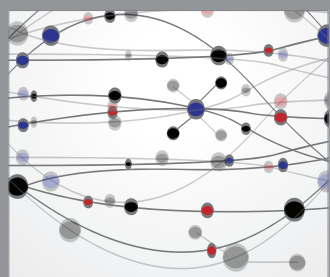

The Scientific World Journal
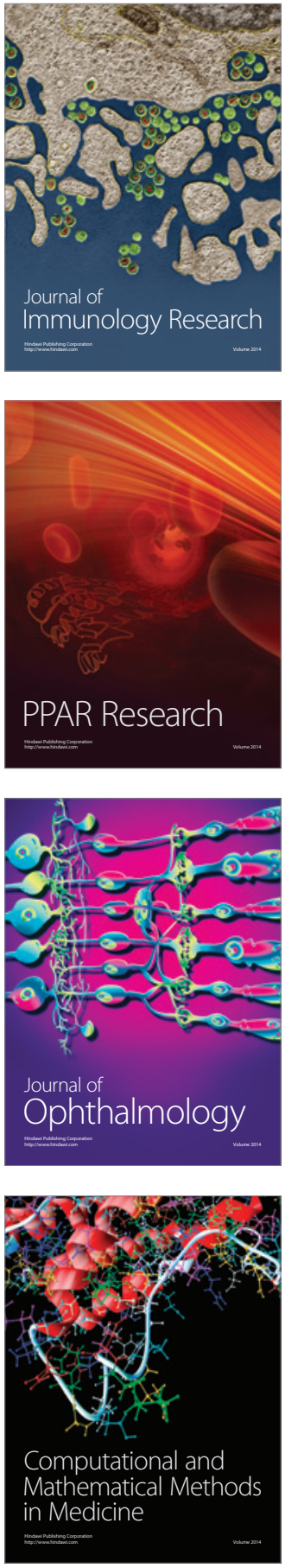

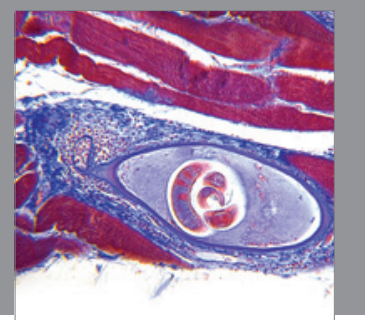

Gastroenterology

Research and Practice
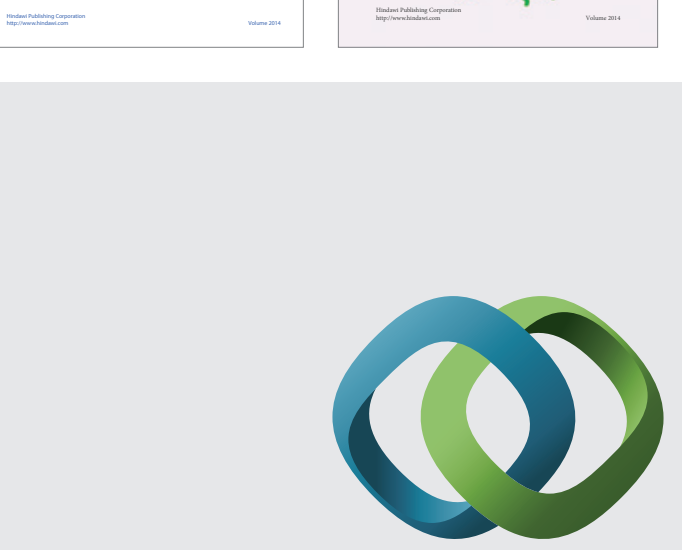

\section{Hindawi}

Submit your manuscripts at

http://www.hindawi.com
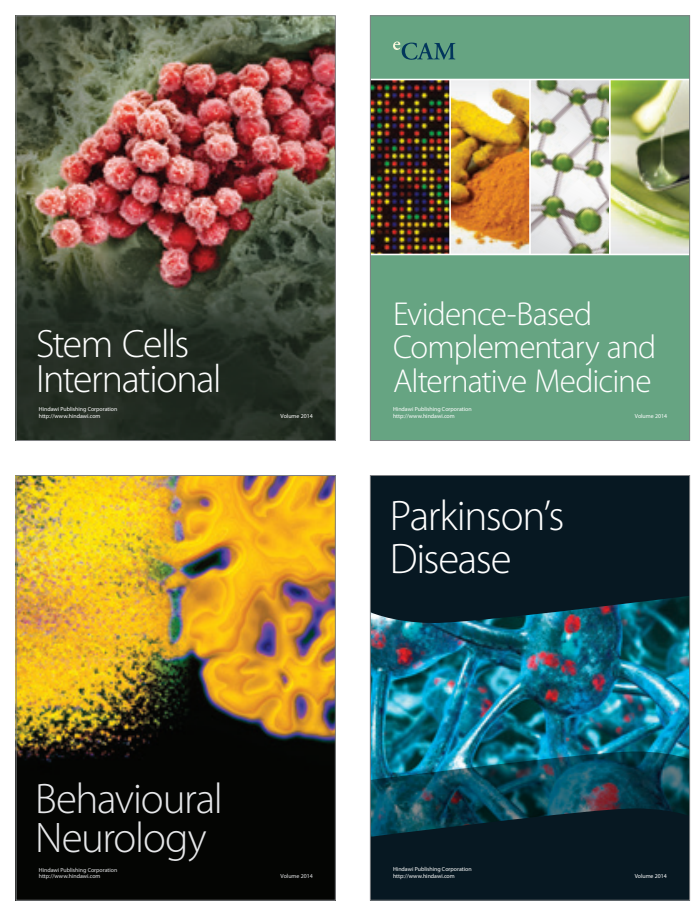

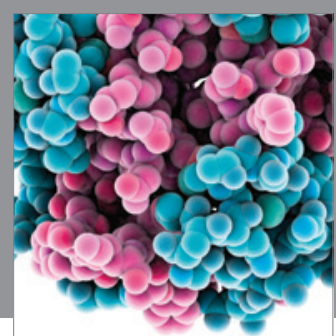

Journal of
Diabetes Research

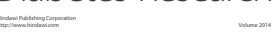

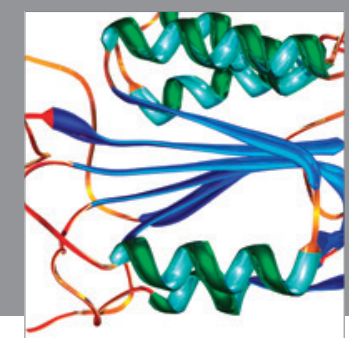

Disease Markers
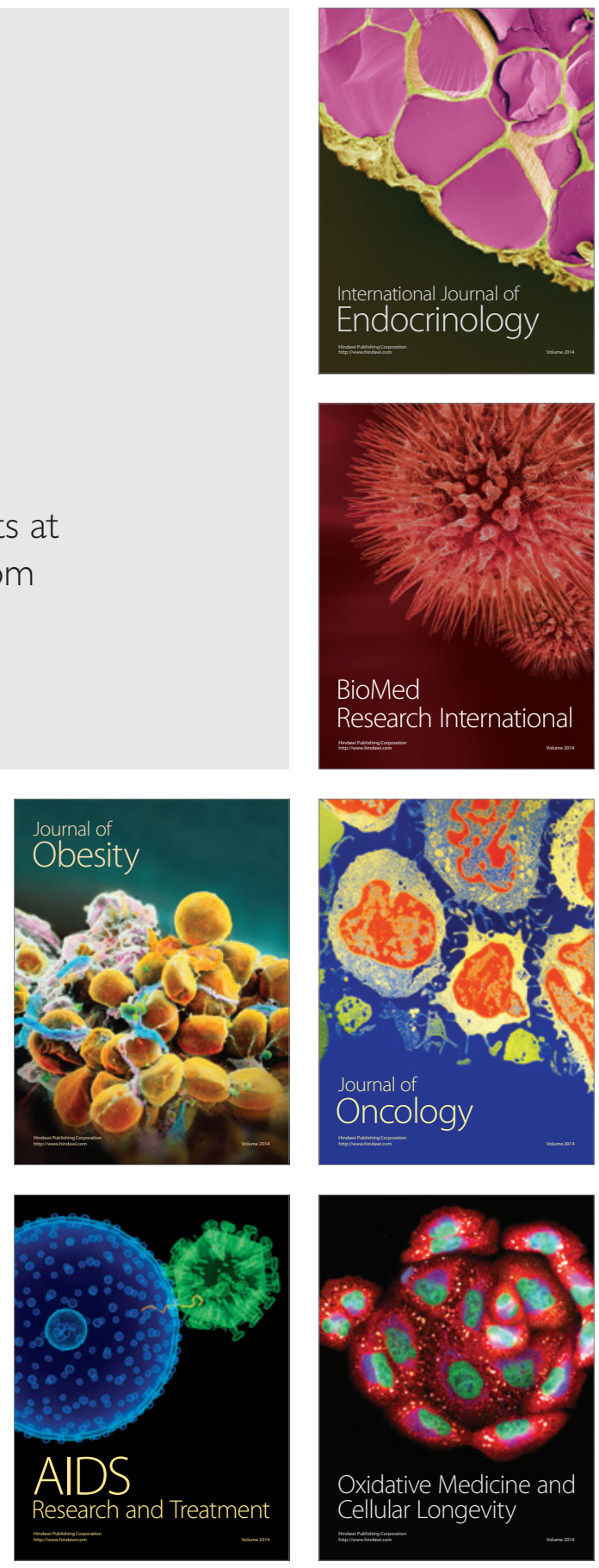